\title{
EARLINET: towards an advanced sustainable European aerosol lidar network
}

\author{
G. Pappalardo ${ }^{1}$, A. Amodeo ${ }^{1}$, A. Apituley ${ }^{2}$, A. Comeron $^{3}$, V. Freudenthaler ${ }^{4}$, H. Linné ${ }^{5}$, A. Ansmann ${ }^{6}$, J. Bösenberg ${ }^{5}$, \\ G. D'Amico ${ }^{1}$, I. Mattis ${ }^{7}$, L. Mona ${ }^{1}$, U. Wandinger ${ }^{6}$, V. Amiridis ${ }^{8}$, L. Alados-Arboledas ${ }^{9}$, D. Nicolae ${ }^{10}$, and \\ M. Wiegner ${ }^{4}$ \\ ${ }^{1}$ Consiglio Nazionale delle Ricerche - Istituto di Metodologie per l'Analisi Ambientale CNR-IMAA, Potenza, Italy \\ ${ }^{2}$ Royal Netherlands Meteorological Institute KNMI, De Bilt, the Netherlands \\ ${ }^{3}$ Universitat Politècnica de Catalunya, Barcelona, Spain \\ ${ }^{4}$ Ludwig-Maximilians-Universität, Munich, Germany \\ ${ }^{5}$ Max-Planck-Institut für Meteorologie, Hamburg, Germany \\ ${ }^{6}$ Leibniz-Institut für Troposphärenforschung, Leipzig, Germany \\ ${ }^{7}$ Deutscher Wetterdienst Hohenpeißenberg, Meteorological Observatory, Hohenpeißenberg, Germany \\ ${ }^{8}$ National Observatory of Athens, IAASARS, Penteli, Greece \\ ${ }^{9}$ CEAMA, Andalusian Center for Environmental Research, University of Granada, Granada, Spain \\ ${ }^{10}$ National Institute of R\&D for Optoelectronics, Magurele, Romania \\ Correspondence to: G. Pappalardo (pappalardo@imaa.cnr.it )
}

Received: 24 February 2014 - Published in Atmos. Meas. Tech. Discuss.: 25 March 2014

Revised: 21 June 2014 - Accepted: 23 June 2014 - Published: 8 August 2014

\begin{abstract}
The European Aerosol Research Lidar Network, EARLINET, was founded in 2000 as a research project for establishing a quantitative, comprehensive, and statistically significant database for the horizontal, vertical, and temporal distribution of aerosols on a continental scale. Since then EARLINET has continued to provide the most extensive collection of ground-based data for the aerosol vertical distribution over Europe.

This paper gives an overview of the network's main developments since 2000 and introduces the dedicated EARLINET special issue, which reports on the present innovative and comprehensive technical solutions and scientific results related to the use of advanced lidar remote sensing techniques for the study of aerosol properties as developed within the network in the last 13 years.

Since 2000, EARLINET has developed greatly in terms of number of stations and spatial distribution: from 17 stations in 10 countries in 2000 to 27 stations in 16 countries in 2013. EARLINET has developed greatly also in terms of technological advances with the spread of advanced multiwavelength Raman lidar stations in Europe. The developments for the quality assurance strategy, the optimization of
\end{abstract}

instruments and data processing, and the dissemination of data have contributed to a significant improvement of the network towards a more sustainable observing system, with an increase in the observing capability and a reduction of operational costs.

Consequently, EARLINET data have already been extensively used for many climatological studies, long-range transport events, Saharan dust outbreaks, plumes from volcanic eruptions, and for model evaluation and satellite data validation and integration.

Future plans are aimed at continuous measurements and near-real-time data delivery in close cooperation with other ground-based networks, such as in the ACTRIS (Aerosols, Clouds, and Trace gases Research InfraStructure Network) www.actris.net, and with the modeling and satellite community, linking the research community with the operational world, with the aim of establishing of the atmospheric part of the European component of the integrated global observing system. 


\section{Introduction}

At present, atmospheric aerosols are considered one of the major uncertainties in climate forcing (Forster et al., 2007; Boucher et al., 2013), and a detailed aerosol characterization is needed in order to understand their role in the atmospheric processes as well as human health and environment. The most significant cause of uncertainty is the large variability in space and time. Due to their short lifetime and strong interactions, their global concentrations and properties are poorly known. For these reasons, information on the large-scale three-dimensional aerosol distribution in the atmosphere should be continuously monitored. Which aerosol parameter must be observed and which resolution and accuracy is required depends strongly on the scientific objective. For example, for radiative studies, it is useful to measure aerosol optical properties, whereas for studies on the impact on the environment and health, it is more relevant to investigate aerosol microphysical properties. Specifically for climate studies related to aerosol-cloud-radiation interaction, it is necessary to measure aerosol optical properties, size, morphology, and composition as a function of time and space, with a high resolution in both domains to account for the large variability. Since it is in particular the information on the vertical distribution that is lacking, advanced laser remote sensing is the most appropriate tool to close the observational gap.

Lidar techniques represent the optimal tool to provide range-resolved aerosol data. Several lidar techniques are suitable for aerosol studies and in the last ten years rapid progress in laser technology, measurement techniques, and data acquisition systems has contributed to a much wider use of these techniques for aerosol monitoring, ranging from the simple elastic backscatter lidar to the most advanced multiwavelength Raman lidar systems.

In the case of an elastic backscatter lidar, the detected wavelength is identical to the transmitted wavelength, and the magnitude of the received signal at a given range depends on the backscatter cross section of scatterers and the transmission along the path to that range (Weitkamp, 2005). Typical operating wavelengths are 355,532 , and $1064 \mathrm{~nm}$. The typical product of a backscatter lidar is the vertical profile of the aerosol backscatter coefficient obtained by assuming a lidar ratio, i.e., the aerosol extinction-to-backscatter ratio. It is necessary to underline that without an a priori assumption about the lidar ratio, or additional constraints provided by auxiliary information such as aerosol optical depth (AOD) or layer transmission, this kind of lidar system cannot provide quantitative aerosol backscatter and extinction data. The Raman lidar (Ansmann et al., 1990, 1992) or High Spectral Resolution Lidar (HSRL) (Shipley et al., 1983) techniques overcome this difficulty by providing independent aerosol extinction and backscatter coefficient measurements. Vertical profiles with high resolution provided by these lidars allow the optical characterization of atmospheric aerosol layers in the planetary boundary layer (PBL) as well as in the free troposphere. The aerosol characterization can be further improved by the use of multiwavelength Raman lidar equipped with depolarization channels and by combination with passive radiometry, e.g., sun photometers. These data can be inverted to provide information about aerosol microphysical properties such as size, shape, refractive index, and effective radius (Müller et al., 1999, 2004; Veselovskii et al., 2002, 2012; Böckmann et al., 2005; Gasteiger et al., 2011). Lidar observations can be even more beneficial if used in coordinated networks. When combined with appropriate atmospheric transport models, they are fundamental for studying aerosols on a large spatial scale and to investigate transport and modification phenomena. These arguments were the motivation for the establishment of EARLINET, the European Aerosol Research Lidar Network (Bösenberg et al., 2001a, 2003) in the year 2000.

This special issue aims at giving an overview of the achievements of EARLINET in the last 13 years. It includes the presentation of innovative and comprehensive technical solutions and scientific results related to the use of advanced lidar remote sensing techniques for the study of aerosol properties. Major topics addressed in this special issue include quality assurance methodologies and tools, calibration techniques, technological solutions for the optimization of lidar system design, advanced and sustainable data processing systems, new algorithms for the retrieval of aerosol properties, and the assessment of different lidar techniques and systems for providing quantitative aerosol information.

This introductory paper presents specific networking topics that are not covered in the individual papers of this special issue. In particular, the EARLINET network and its main developments in the last 13 years are presented in Sect. 2. Section 3 presents the fundamental activities, which are the basis for the establishment and achievements of the EARLINET network towards a sustainable observation system. Section 4 provides a selection of relevant scientific results obtained using the EARLINET data. A summary with an outlook and brief description of future plans concludes this paper.

\section{EARLINET overview}

EARLINET (www.earlinet.org) was established in 2000 (Bösenberg et al., 2001a, 2003) as a research project funded by the European Commission, within the Fifth Framework Programme, with the main goal of providing a comprehensive, quantitative, and statistically significant database for the aerosol distribution on a continental scale. After the end of this 3-year project, the network activity continued based on a voluntary association. The objectives of the association, as reported in the EARLINET Constitution and Bylaws (EARLINET General Assembly in Matera, 2004, www.earlinet.org), are to promote cooperation and discussion in Europe among scientists concerned with studies of 
aerosol remote sensing by means of lidars and to promote and encourage the development of any or all of the relevant sciences. The network activity continued successfully and in 2006 the 5-year EC Project EARLINET-ASOS (Advanced Sustainable Observation System) started on the basis of the EARLINET infrastructure.

The main objectives of the EARLINET-ASOS project were

- to extend the development of the European Aerosol Research Lidar Network as a world-leading instrument for the observation of the four-dimensional spatiotemporal distribution of aerosols on a continental scale, resulting in accurate, well-defined, and easily accessible data products for use in science and environmental services.

- to enhance the operation of the network to foster aerosol-related process studies, validation of satellite sensors, model development and validation, and assimilation of aerosol data into operational models, and to build a comprehensive climatology of the aerosol distribution.

These objectives were achieved by defining and using common standards for instruments, operating procedures, observational schedules, data processing including advanced retrieval algorithms, and dissemination of data. The EARLINET-ASOS project strongly contributed to optimizing the operation of the network. EARLINET is now integrated in the FP7 EU research infrastructure project ACTRIS (Aerosols, Clouds, and Trace gases Research InfraStructure Network, www.actris.net) that will, for the first time, provide coordinated observations of the major atmospheric variables.

In the first 13 years of its existence, EARLINET has strongly increased its observing capacity. Currently, EARLINET is composed of 27 active stations; a station is considered active when submitting aerosol extinction and/or backscatter coefficient profiles to the EARLINET database. Furthermore, six stations are members of EARLINET but not currently contributing, either because they are newly admitted stations, with instruments not yet ready or undergoing quality assurance tests, or because they are facing operational problems. Figure 1 shows the geographical distribution of today's active EARLINET stations.

The stations can be classified in the following categories according to their capabilities:

1. Multiwavelength Raman lidar stations (red dots in Fig. 1) that combine elastic and $\mathrm{N}_{2}$ Raman channels, complying with the so-called "EARLINET core stations" (Pappalardo et al., 2010) of a minimum of three elastic channels (corresponding usually to the $1064 \mathrm{~nm}$ fundamental wavelength of the Nd: YAG laser, and to the wavelengths of the second and third harmonics, at $532 \mathrm{~nm}$ and $355 \mathrm{~nm}$, respectively) and two Raman channels, shifted $2330 \mathrm{~cm}^{-1}$ down the excitation frequencies (usually at $607 \mathrm{~nm}$ and $387 \mathrm{~nm}$ wavelengths) and

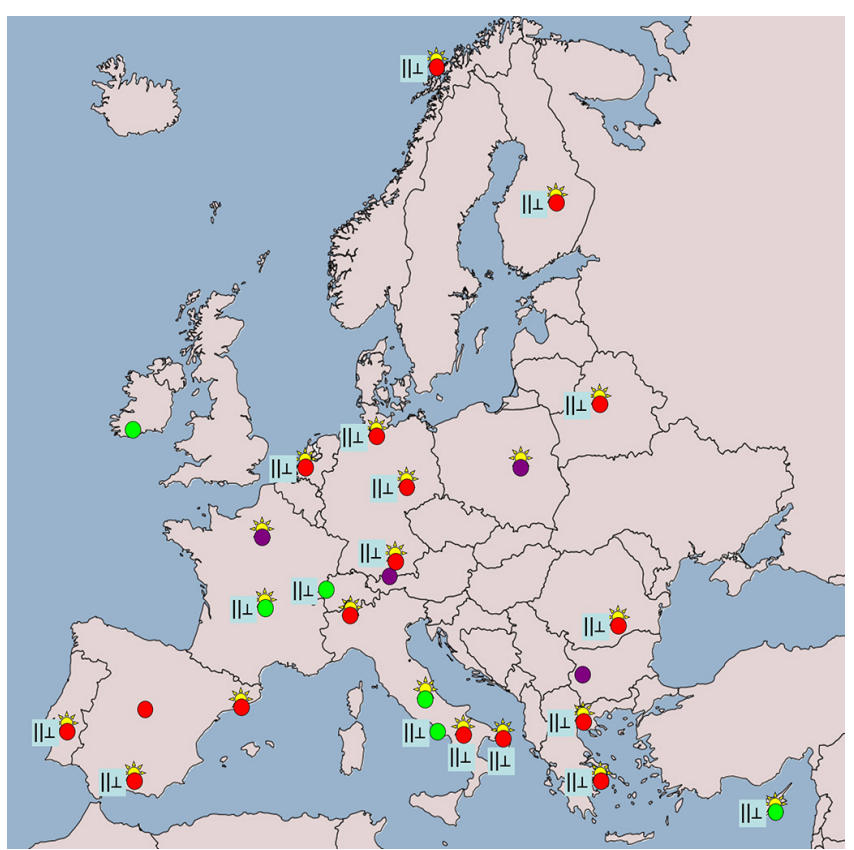

Figure 1. Map of the EARLINET stations currently active. Red dots indicate multiwavelength Raman lidar stations (EARLINET core stations). Green dots correspond to stations with at least one Raman channel. Violet dots denote lidars with only elastic backscatter channels. The $\| \perp$ symbol indicates that the station has depolarization-measurement capabilities. The "sun" symbol means collocation with an AERONET sun photometer.

corresponding to the $\mathrm{Q}, \mathrm{O}$, and $\mathrm{S}$ branches of the $\mathrm{N}_{2}$ vibrational-rotational Raman spectrum. For these systems, the combination of three backscatter coefficient profiles and two extinction coefficient profiles obtained without resorting to an assumed lidar ratio $(3+2$ configuration) allows advanced aerosol typing, able to provide, in addition to lidar ratio and Ångström exponents, range-resolved microphysical properties of the aerosols, such as particle effective radius, radius distribution, volume concentration, and refractive index (Böckmann, 2005; Müller et al., 1999, 2004; Veselovskii et al., 2002).

2. Raman lidar stations (green dots in Fig. 1), which operate at least one Raman channel permitting the retrieval of extinction coefficient profiles without assumptions. They allow the determination of the lidar ratio, gaining useful information on the aerosol type.

3. Backscatter lidar stations (violet dots in Fig. 1), without Raman channels, which must rely on an estimate of the lidar ratio to retrieve the backscatter and extinction coefficient profiles.

Furthermore, 18 EARLINET stations operate depolarization channels $(\| \perp$ symbol in Fig. 1) that measure the depolarization of the emitted linearly polarized radiation, yielding 
as a product the aerosol particle linear depolarization ratio which enhances the aerosol typing capabilities by providing information on the particle shape.

In addition, 21 EARLINET stations are collocated with AErosol RObotic NETwork (AERONET) sun photometers (sun symbol in Fig. 1), which allows the synergetic exploitation of lidar and sun-photometer data during daytime hours, thus providing range-resolved information for the otherwise column-integrated sun-photometer products. Table 1 summarizes the locations and capabilities of the EARLINET stations.

The exchange of expertise fostered by EARLINET since its inception in 2000, together with specific efforts to optimize the instruments, in particular within the framework of the EARLINET-ASOS project, has been paramount in achieving the present status of the network. The development of the characteristics of the instruments is described in Fig. 2a and b. At the start of EARLINET, backscatter lidars, some of them multiwavelength, were predominant in the network. Within the EARLINET-ASOS project most of the backscatter lidars were first upgraded to single-wavelength Raman lidars and finally towards multiwavelength Raman lidars that currently form the most frequent class. As to the depolarization-measurement capabilities, the number of systems featuring depolarization channels has grown from 2 in the year 2000 to 18 .

\section{EARLINET pillars}

The overarching EARLINET pillar is the systematic performance of lidar observations. EARLINET observations are performed on a regular schedule of one daytime measurement per week (Monday) around noon, when the PBL is usually well developed, and two nighttime measurements per week (Monday and Thursday), with low background light, in order to perform Raman extinction measurements. In addition to these systematic measurements for the consolidation of a European aerosol climatology, further observations are devoted to monitor special events over the continent, such as Saharan dust outbreaks, forest fires, photochemical smog, and volcanic eruptions. Moreover, EARLINET started correlative measurements during overpasses of CALIPSO, the NASA-CNES (Centre National d'Etudes Spatiales, France) satellite mission "CloudAerosol Lidar and Infrared Pathfinder Satellite Observation" on 14 June 2006, during the commissioning phase of CloudAerosol Lidar with Orthogonal Polarization (CALIOP), the CALIPSO lidar (Winker et al., 2009). A strategy for correlative measurements has been defined on the basis of the analysis of the ground track data provided by NASA (Pappalardo et al., 2010).

EARLINET measurements must meet stringent stability and absolute accuracy standards to achieve the desired confidence in aerosol radiative forcing needs; thus, the network
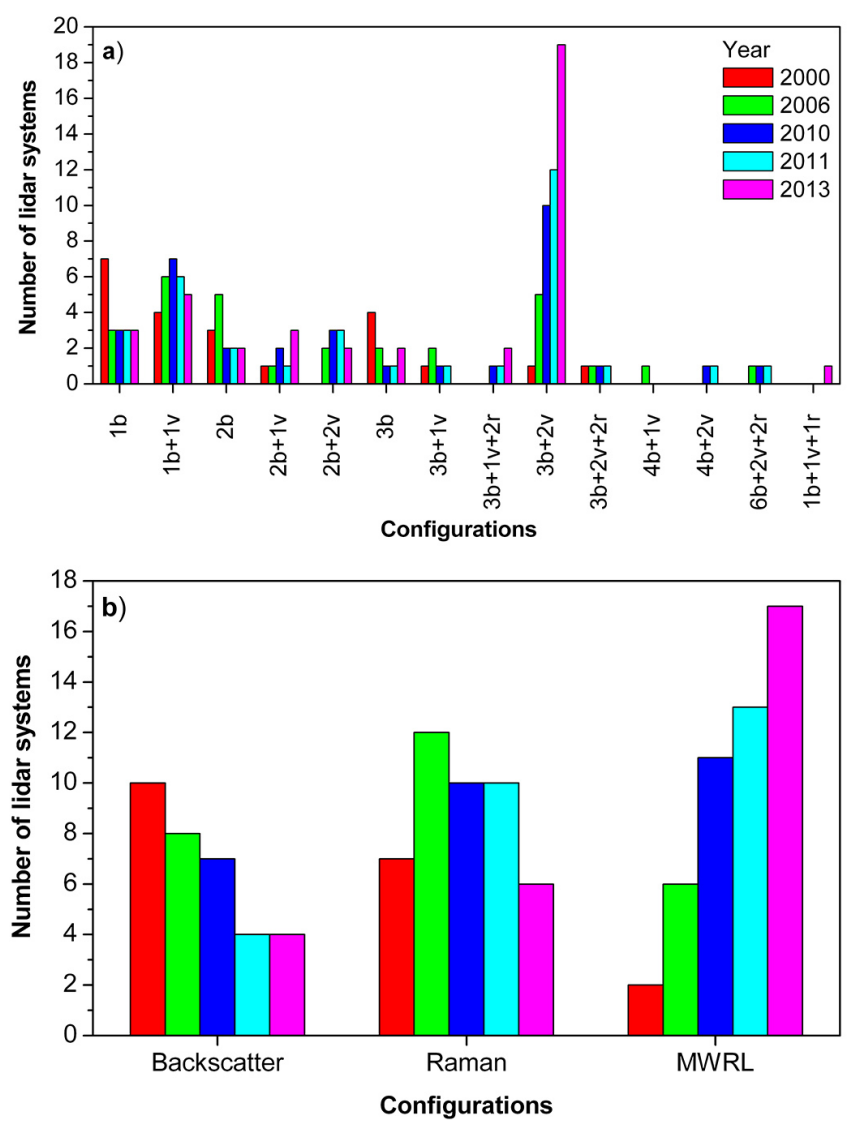

Figure 2. Development of the number of lidar systems by their configurations in EARLINET between 2000 (the start of EARLINET) and 2013. Configurations are classified by (a) detailing the receiving system ("b" for backscatter, "v" for vibrational Raman, and " $r$ " for rotational Raman, where the number before each letter indicates the number of wavelengths for which the "b", "v", and " $r$ " are measured) and (b) grouping the receiving systems in larger configuration classes: backscatter lidars, Raman lidars, multiwavelength Raman lidars (MWRL).

has developed a rigorous quality assurance program addressing both instrument performance (Matthias et al., 2004a; Freudenthaler et al., 2010) and evaluation of the algorithms (Böckmann et al., 2004; Pappalardo et al., 2004a). These operational pillars have been developed to ensure instrument standardization and consistent lidar retrievals within the network in a standardized data exchange format and are described in the following sections.

\subsection{Quality assurance}

Homogeneous and well-established data quality is one of the key conditions for the combined use of data originating from different systems. Because the establishment of a joint data set and its use in comparative studies are major objectives of EARLINET, specific attention is given to data quality assurance. The EARLINET quality assurance (QA) program has been developed for both hardware and retrieval algorithms, 
Table 1. Active EARLINET stations. Depol: aerosol depolarization-measurement capability; SP: collocated AERONET sun photometer; MWRL: multiwavelength Raman lidar; RL: Raman lidar; BL: backscatter lidar.

\begin{tabular}{|c|c|c|c|c|}
\hline Station & Coordinates & Type & Depol. & SP \\
\hline Andenes, Norway & $69^{\circ} 17^{\prime} \mathrm{N}, 16^{\circ} 0^{\prime} \mathrm{E}$ & MWRL & $\mathrm{X}$ & $\mathrm{X}$ \\
\hline Athens, Greece & $37^{\circ} 58^{\prime} \mathrm{N}, 23^{\circ} 47^{\prime} \mathrm{E}$ & MWRL & $\mathrm{X}$ & $\mathrm{X}$ \\
\hline Barcelona, Spain & $41^{\circ} 23^{\prime} \mathrm{N}, 2^{\circ} 7^{\prime} \mathrm{E}$ & MWRL & & $\mathrm{X}$ \\
\hline Belsk, Poland & $51^{\circ} 50^{\prime} \mathrm{N}, 20^{\circ} 47^{\prime} \mathrm{E}$ & BL & & \\
\hline Bucharest, Romania & $44^{\circ} 27^{\prime} \mathrm{N}, 26^{\circ} 2^{\prime} \mathrm{E}$ & MWRL & $\mathrm{X}$ & $\mathrm{X}$ \\
\hline Cabauw, The Netherlands & $51^{\circ} 58^{\prime} \mathrm{N}, 4^{\circ} 56^{\prime} \mathrm{E}$ & MWRL & $\mathrm{X}$ & $\mathrm{X}$ \\
\hline Clermont-Ferrand, France & $45^{\circ} 46^{\prime} \mathrm{N}, 3^{\circ} 7^{\prime} \mathrm{E}$ & $\mathrm{RL}$ & $\mathrm{X}$ & $\mathrm{X}$ \\
\hline Cork, Ireland & $51^{\circ} 54^{\prime} \mathrm{N}, 8^{\circ} 30^{\prime} \mathrm{W}$ & RL & & \\
\hline Évora, Portugal & $38^{\circ} 34^{\prime} \mathrm{N}, 7^{\circ} 55^{\prime} \mathrm{W}$ & MWRL & $\mathrm{X}$ & $\mathrm{X}$ \\
\hline Garmisch-Partenkirchen, Germany & $47^{\circ} 29^{\prime} \mathrm{N}, 11^{\circ} 4^{\prime} \mathrm{E}$ & $\mathrm{BL}$ & & \\
\hline Granada, Spain & $37^{\circ} 10^{\prime} \mathrm{N}, 3^{\circ} 36^{\prime} \mathrm{W}$ & MWRL & $\mathrm{X}$ & $\mathrm{X}$ \\
\hline Hamburg, Germany & $53^{\circ} 34^{\prime} \mathrm{N}, 9^{\circ} 58^{\prime} \mathrm{E}$ & MWRL & $\mathrm{X}$ & $\mathrm{X}$ \\
\hline Ispra, Italy & $45^{\circ} 48^{\prime} \mathrm{N}, 8^{\circ} 36^{\prime} \mathrm{E}$ & MWRL & & $\mathrm{X}$ \\
\hline Kuopio, Finland & $62^{\circ} 44^{\prime} \mathrm{N}, 27^{\circ} 33^{\prime} \mathrm{E}$ & MWRL & $\mathrm{X}$ & $\mathrm{X}$ \\
\hline L'Aquila, Italy & $42^{\circ} 23^{\prime} \mathrm{N}, 13^{\circ} 19^{\prime} \mathrm{E}$ & RL & & \\
\hline Lecce, Italy & $40^{\circ} 18^{\prime} \mathrm{N}, 18^{\circ} 6^{\prime} \mathrm{E}$ & MWRL & $\mathrm{X}$ & $\mathrm{X}$ \\
\hline Leipzig, Germany & $51^{\circ} 21^{\prime} \mathrm{N}, 12^{\circ} 26^{\prime} \mathrm{E}$ & MWRL & $\mathrm{X}$ & $\mathrm{X}$ \\
\hline Limassol, Cyprus & $34^{\circ} 40^{\prime} \mathrm{N}, 33^{\circ} 23^{\prime} \mathrm{E}$ & $\mathrm{RL}$ & $\mathrm{X}$ & $\mathrm{X}$ \\
\hline Madrid, Spain & $40^{\circ} 27^{\prime} \mathrm{N}, 3^{\circ} 44^{\prime} \mathrm{W}$ & MWRL & & \\
\hline Maisach, Germany & $48^{\circ} 13^{\prime} \mathrm{N}, 11^{\circ} 15^{\prime} \mathrm{E}$ & MWRL & $\mathrm{X}$ & $\mathrm{X}$ \\
\hline Minsk, Belarus & $53^{\circ} 55^{\prime} \mathrm{N}, 27^{\circ} 36^{\prime} \mathrm{E}$ & MWRL & $\mathrm{X}$ & $\mathrm{X}$ \\
\hline Naples, Italy & $40^{\circ} 50^{\prime} \mathrm{N}, 14^{\circ} 11^{\prime} \mathrm{E}$ & MWRL & $\mathrm{X}$ & \\
\hline Palaiseau, France & $48^{\circ} 42^{\prime} \mathrm{N}, 2^{\circ} 12^{\prime} \mathrm{E}$ & $\mathrm{BL}$ & & $\mathrm{X}$ \\
\hline Payerne, Switzerland & $46^{\circ} 49^{\prime} \mathrm{N}, 6^{\circ} 56^{\prime} \mathrm{E}$ & RL & $\mathrm{X}$ & \\
\hline Potenza, Italy & $40^{\circ} 36^{\prime} \mathrm{N}, 15^{\circ} 43^{\prime} \mathrm{E}$ & MWRL & $\mathrm{X}$ & $\mathrm{X}$ \\
\hline Sofia, Bulgaria & $42^{\circ} 40^{\prime} \mathrm{N}, 23^{\circ} 20^{\prime} \mathrm{E}$ & $\mathrm{BL}$ & & \\
\hline Thessaloniki, Greece & $40^{\circ} 38^{\prime} \mathrm{N}, 22^{\circ} 57^{\prime} \mathrm{E}$ & MWRL & $\mathrm{X}$ & $\mathrm{X}$ \\
\hline
\end{tabular}

and it is based on intercomparisons and quality check tools developed ad hoc.

EARLINET consists of quite different lidar systems regarding the number of measured wavelengths and signal channels, the detection range, which is mainly determined by laser power and telescope size and number, the optical design, and the electronic signal detection techniques. Reasons for this variety are that lidar systems are quite expensive, mostly developed by research groups with different backgrounds, aims, and financial capabilities, and that expensive technical improvements can often only be implemented step by step and gradually over years. Such different systems contain many different systematic error sources. Furthermore, a lidar system consists of several parts or subsystems; these mainly contain an optical part comprising the laser beam, telescope, and beam-splitting and -shaping optics. Furthermore, they contain an electronic part comprising the detectors and data acquisition, including the trigger electronics of the laser, and the signal analysis part, which consists of the software. Each part contains its individual errors that may often not be discerned from each other, making a systematic error analysis and consequential system improvement very difficult.
The goal of the EARLINET QA program was to improve this situation wherever possible and to homogenize the different approaches of the individual research groups towards common quality criteria for the lidar products in the EARLINET database. Several papers of this special issue describe the different aspects of this effort.

As an overall calibration is not possible, methods and tools have been collected and developed to determine deviations on subsystem levels and to identify and assess the impact of critical subsystems by means of analytical methods. Freudenthaler et al. (2014) describes mandatory quality checkups for each lidar system, some of which have to be performed regularly every year, some only once, in order to assess the performance and the temporal stability of a lidar system.

One-time checkups are the test of the accuracy limits of the analog detection systems due to signal-induced distortions; they are carried out by means of a specialized electronic lidar test-pulse generator, developed within the framework of EARLINET, and the trigger-delay test, with which the accuracy of the zero-range for the range correction can be determined. The latter is important because extreme errors of the retrieved optical properties in the near range are introduced if 
the zero-range is wrong by a few meters. Checkups that have to be performed every year or in case of a significant change or upgrade in the lidar system configuration in order to verify the long-term stability of a lidar systems are the "dark measurement", the "telecover test", and the "Rayleigh fit". The dark measurement records all signal components other than atmospheric returns and reveals systematic and random electronic signal interspersion, e.g., from the trigger system or other electronic equipment. The telecover test checks the consistency of the range-dependent transmission of the optical receiver by comparing the signals acquired by different parts of the receiving telescope. Differences are a relative measure for the range dependency of the overlap function and can be used to estimate the optical part of the lidar signal uncertainty, especially in the near range. The far-range lidar signal can be calibrated with a fit to the so-called Rayleigh signal; a signal calculated from the height-dependent molecular density of the atmosphere, which is best determined by coincident and collocated radiosonde data. For this test it has to be assumed that the height range where the calculated and the measured signals are compared is free of aerosols and clouds. These tests are described in detail in Freudenthaler et al. (2014).

Systematic errors in lidar signals often stem from an inaccurate optical design of the receiver optics or from imperfect optical parts like dichroic beam splitters. The impact of such flaws and possible improvements have been investigated with optical ray tracing (Freudenthaler et al., 2014) and by means of the Müller-Stokes formalism (Freudenthaler, 2014). Optical ray tracing helps to determine the theoretical limits of the optical design of lidar receivers, especially regarding the range-dependent transmission (overlap function). It showed that the design of many optical receivers is close to the theoretical limits, which does not leave margins for the toleration of inevitable thermal and mechanical instabilities and optical alignment inaccuracies.

The polarization-sensitive transmission (diattenuation) of inclined optical parts in the receiver optics, like beam splitters, mirrors, and filters, which has been generally neglected in the past, causes systematic errors in all lidar signals (Mattis et al., 2009; Freudenthaler et al., 2009). Especially polarization-sensitive lidar systems suffer from this effect. A rigorous treatment of this effect with the Müller-Stokes formalism is presented in Freudenthaler (2014), and BravoAranda et al. (2014) and Belegante et al. (2014) present experimental examples and results of the application of this theory.

The final quality check of an EARLINET lidar is the direct comparison with a reference lidar system. Since the beginning of EARLINET, several direct lidar comparisons have been performed, and from the outcome the best lidar systems have been selected as reference systems. A requirement for this was that such a reference system must be mobile to be transported to other stationary lidar systems for comparison and that it comprises a minimum number of wavelengths.
These reference systems were checked against each other during EARLI09 (EArlinet Reference Lidar Intercomparison 2009) in Leipzig, Germany, in 2009 (Wandinger et al., 2014). The results from a similar comparison campaign in the first stage of EARLINET are presented in Matthias et al. (2004a).

The EARLINET QA program for retrieval algorithms is mainly based on intercomparison exercises of aerosol backscatter lidar and Raman lidar algorithms used by the different groups. These intercomparisons are based on synthetic lidar signals simulated ad hoc in order to test the correctness of the algorithms and the influence of the lidar ratio profile, the reference value, and the temperature and pressure profiles on the retrieved backscatter and extinction coefficient profiles (Böckmann et al., 2004; Pappalardo et al., 2004a). Moreover synthetic lidar signals, both elastic and Raman, are also used by each group for testing new algorithm development as an internal quality assurance tool.

However, the different methods used to analyze and invert lidar signals into aerosol optical properties such as extinction and backscatter coefficients, and lidar and depolarization ratios use mathematical techniques with different spatial filter techniques and approximations, and hence introduce additional random or systematic differences and errors among all distinct inversion approaches. To avoid inconsistencies in the signal inversion and the error calculation, and to automate the evaluation process, a common data scheme, the socalled single calculus chain (SCC), was developed within the framework of EARLINET (D'Amico et al., 2014a, b; Mattis et al., 2014). The paper by Amodeo et al. (2014) presents the consolidated error calculation used in the SCC.

\subsection{Optimization of instruments}

A further pillar of the EARLINET network is the homogenization and optimization of the performance of the contributing lidar systems. Increasing performance will enable the network to provide data of better quality and a larger number of delivered parameters. In addition, standardization of systems leads to improved interoperability in future networks and in a more general integrated observing system.

The key elements for the instrument development are as follows:

- Optimal performance for the main data products of the lidars for aerosol profiling: i.e., profiles of aerosol backscatter coefficient, aerosol extinction coefficient, and lidar ratio. The minimum recommendation is to add a nitrogen Raman channel to a backscatter lidar. For a candidate EARLINET core station, the implementation of a multiwavelength Raman lidar is recommended.

- Daytime performance: aerosol optical properties play their most important role during daytime. Aerosol characteristics can change in relatively short periods of time, e.g., the lidar ratio obtained during nighttime measurements can significantly differ from daytime conditions. 
Therefore, daytime measurements of the aerosol optical properties are needed; that means that Raman lidars, which are typically operated during nighttime only, must be upgraded for daytime operation. Technical solutions to accomplish this were investigated within the framework of EARLINET.

- Increased operationality: as lidar measurements normally are quite expensive in terms of maintenance and manpower, an increased automation in instrument control is urgently required so that more data for aerosol characterization will become available.

Contrary to some other atmospheric observation networks, such as MPLNET (Micro-Pulse Lidar Network, mplnet.gsfc. nasa.gov) and AERONET (aeronet.gsfc.nasa.gov), that are largely based on standardized and even commercialized instruments, most EARLINET stations use lidar systems that were not serially produced. As an illustration, a few pictures of EARLINET lidars are shown in Fig. 3. Although the measurement principle is the same, these instruments vary in setup and construction. As a consequence, the performance of the individual instruments can be significantly different, for instance with respect to the altitude range covered, the number of operating wavelengths, or the integration time needed for the measurements to reach a sufficient signal to noise ratio.

The homogenization of the network instruments was approached through a survey of the various solutions existing at individual stations for the components and subsystems. The specifications of the systems are compiled in detail in the "Handbook of Instruments" (HoI). It consists of more than 100 parameters for each detection channel including laser emitter parameters, such as the number of wavelengths and emitted power; detailed information about the optical and geometrical configuration, such as the number of receiving telescopes; as well as parameters related to the optical and electronic detection for each channel of the lidar instrument. As a result, a detailed insight into the properties in each EARLINET lidar system can be obtained.

The individual systems are described in tables, giving the main system characteristics. Since it is not possible to list all parameters in this paper, a schematic of the setup of the HoI is presented in Fig. 4. As shown in Fig. 4, the tables are divided into several sections. First the identification of the lidar station and instrument is recorded. Next, the emitter is described. By putting columns side by side, it is possible to include more than one laser in the table and it is possible to see which type of lasers are used in the emitter and which wavelengths they produce, as well as with which characteristics, related to the emitted beam, or sometimes multiple beams. The same approach is used for the receiver. It is not uncommon that two or more receiving telescopes are used by a single lidar system. The main characteristics of each telescope are tabulated, followed by a section listing the detection channels. In some configurations the same wavelength is received by more than one telescope, so multiple detection channels can also be found for one wavelength. Next, the characteristics of the amplification and digitization of the electrical signals from each detector are listed. Also, any change of the lidar system is uniquely documented. If necessary, the number of parameters can be expanded.

The final two sections in the table describe the mode of operation and which ancillary data is available at the measurement site. Although this is not directly related to the performance of the lidar instrument, it is quite important for the application of data and for the potential of synergistic approaches.

The HoI also contains essential information needed for data processing (photon-counting dead time, overlap function, etc.). It was therefore decided that the HoI should be implemented as a relational database. Each configuration change is entered into the database including the date of implementation. In this way, each measurement is linked to the specific instrument configuration parameters which are needed for the data processing. This system allows the tracking of the possible changes for a specific system, which is essential for consistent long-term data from a distributed network. An overview of technical solutions underlining the development of the network instruments as summarized in this section is given in an accompanying paper (Apituley et al., 2014).

\subsection{Optimization of data processing}

The optimization of data processing is based on the idea of developing a common and automatic processing calculus system for the evaluation of lidar data measured with the instruments operating within EARLINET, from raw signals to final products, i.e., profiles of optical properties, in particular aerosol backscatter and extinction coefficients.

A common calculus system for the network should allow uniformity of the data analysis, standardization of the data product formats, control of the data's quality, assessment of the errors, near-realtime analysis, and product provision. Moreover, it is a prerequisite for the sustainability of the network because it allows us to increase the amount of available products and also to reduce the time needed for data analysis, both with routine measurements and during special and intensive observational measurement campaigns.

The concept of a common data processing system was initiated a few years after the constitution of EARLINET. During the EARLINET-ASOS project it became one of the main goals to be reached, laying the foundations for its implementation and developing the first prototype (Amodeo et al., 2007). As part of the ACTRIS project, an operational version is finally made available.

The development of the common processing calculus system, the SCC, can be considered as a real challenge because of the heterogeneous structure of a network such as 


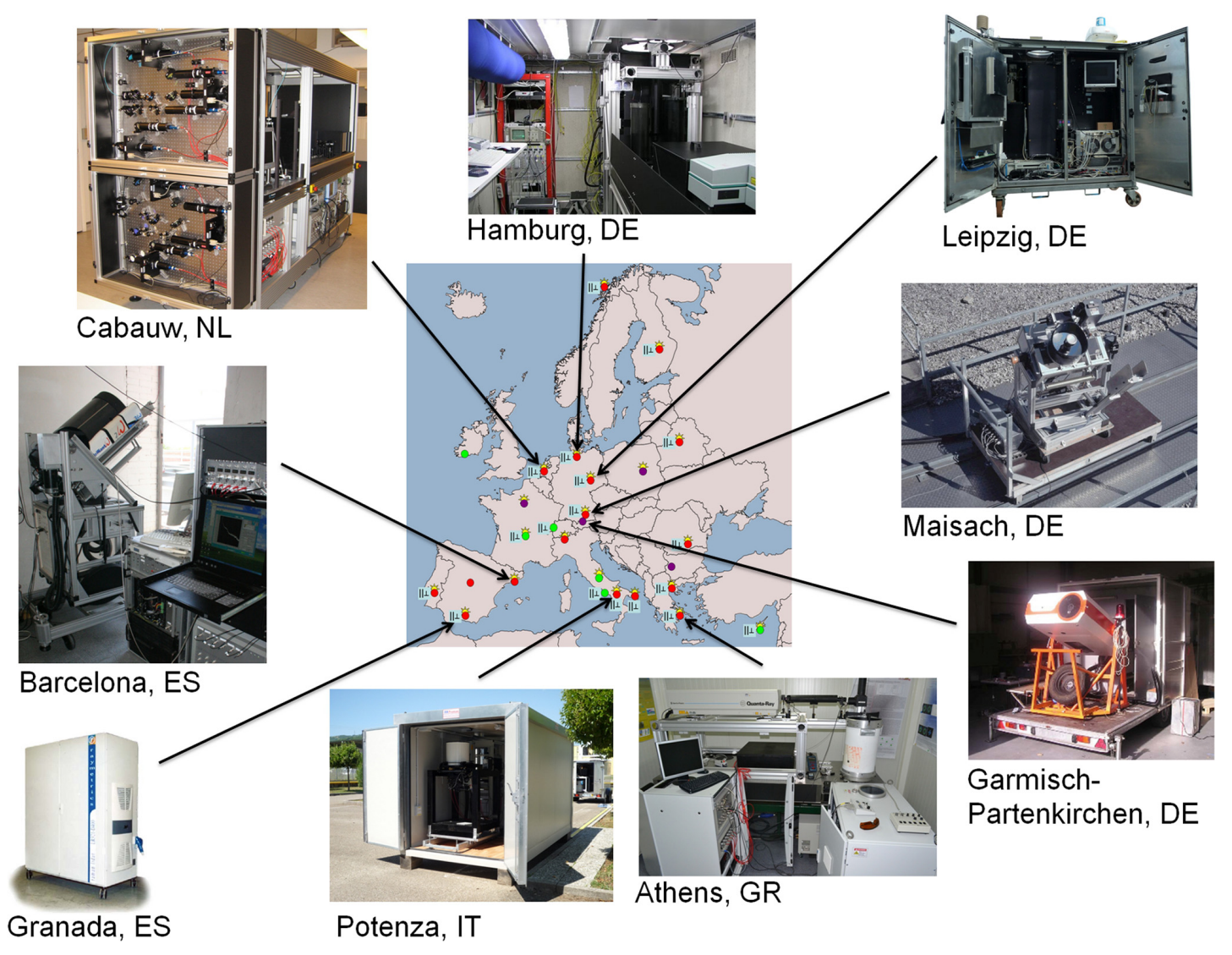

Figure 3. Pictures of a selection of individual lidar systems that are part of EARLINET.

EARLINET. The main difficulty consisted in the fact that the instruments used by the individual groups are different. Differences exist for the wavelengths used, acquisition mode (analog and/or photon-counting), spatial resolution, and detection systems. For this reason, all the possible processing algorithms should be implemented and optimized in the EARLINET SCC.

The EARLINET SCC has been designed to be very flexible and is characterized by the following features:

- platform independence

- open-source philosophy

- netCDF as standard data format

- flexibility allowing the user to choose the retrieval procedure suitable for his/her own instrument;

- easy expandability allowing the handling of data from new and upgraded lidar systems

- operability both on a central single server accessible from the web and on a local server or PC.
The SCC allows us, automatically and without any operator interaction, to retrieve aerosol optical properties, such as extinction and backscatter coefficients, lidar ratio, optical depth, and the Ångström exponent if Raman lidar signals are available. In cases when only elastic lidar signals are used, backscatter and a backscatter-related Ångström exponent are derived.

The SCC as a whole is presented in more detail in D'Amico et al. (2014a). Here only a brief outline is given. In general, the structure of the SCC consists of different modules:

- The pre-processing module: gets system-specific parameters from the SCC database; checks if the raw data are from a lidar system that passed all the required instrumental quality checks; reads netCDF input raw lidar signals; performs several corrections and handling on lidar signals; calculates molecular profile; provides time averaging depending on the product; and calculates the statistical error of pre-processed lidar signals. More details are given in D'Amico et al. (2014b).

- The optical processing module reads the intermediate netCDF file produced by the pre-processing module; gets information from the SCC database; performs 


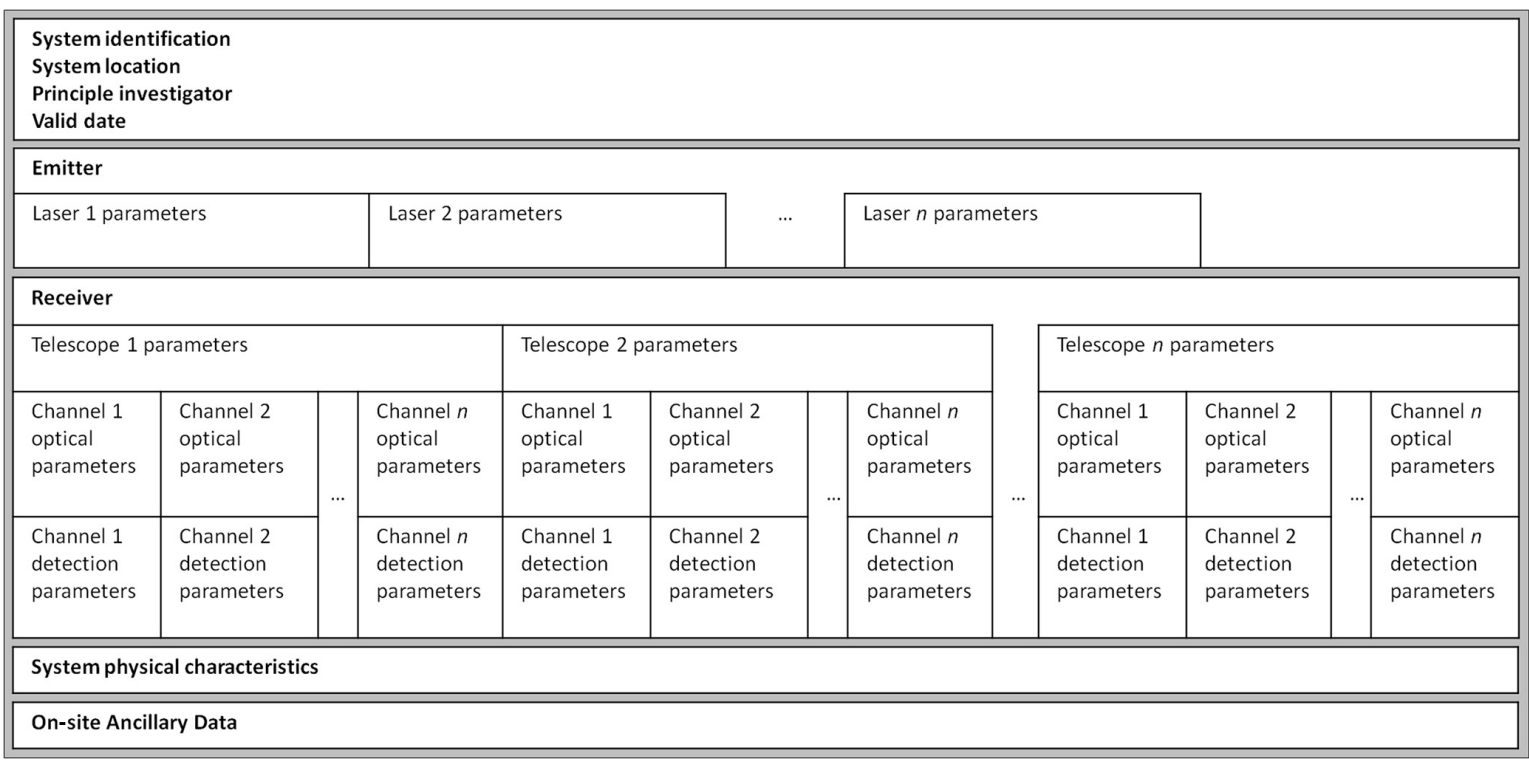

Figure 4. Schematic representation of an instrument table from the EARLINET Handbook of Instruments. The structure allows for multiple emitting lasers (with multiple beams) and a multi-telescope receiving system. As a result, each detection channel is fully characterized. Also, any change or expansion of the lidar system can be uniquely documented.

analysis in a flexible way using the algorithm and analysis procedure selected by the user; retrieves aerosol extinction and backscatter profiles (and lidar ratio profiles); retrieves backscatter either from elastic lidar signal alone or from Raman and elastic signals; calculates the statistical error of extinction and backscatter coefficients; and transfers output files to the EARLINET database in netCDF format according to the EARLINET rules. This is presented in detail in Mattis et al. (2014).

- The daemon software organizes the batch mode of the different calculus modules (sending start or stop commands, handling of errors etc.).

- The SCC database is the tool with which system specific parameters are stored.

- The web interface provides a front end for the relational SCC database. This user interface allows the station manager to set system-specific parameters (e.g., wavelengths used), to upload the raw signals and to start the analysis.

In the future, the inclusion of a module for the retrieval of microphysical properties is also planned.

The EARLINET SCC structure has been designed in such a way that the optimization of data processing is strictly linked to the quality assurance. Raw lidar signals are accepted for analysis only if the corresponding lidar system has passed all the required quality checks, both at algorithm and instrument levels. This information is periodically updated in the SCC database. The SCC also includes tools to check the quality of the raw signals submitted. Thus, low-quality raw lidar signals (in terms, e.g., of signal-to-noise ratio, distortions, and far-range dynamics) are not accepted for analysis.

Through the SCC database, the optimization of data processing is also linked to the optimization of instruments. The SCC database is directly linked to the HoI containing the information of the setup parameters of the instruments. The optimization of data processing also takes into account changes in parameters and configurations that result from the observational and instrumental improvements produced by the research related to the optimization of instruments.

Of course, the optimization of data processing is also linked to the EARLINET database. The SCC products are automatically uploaded into EARLINET database and therefore the products must fulfill all the requirements for the database in terms of file name conventions, content, format, data quality flags, software version, etc.

\subsection{Database}

It is one of the central objectives of EARLINET to provide all internal and external users with a single location where they can access all data from all EARLINET stations in a homogeneous way. This has been accomplished by establishing the EARLINET data center at the Max Planck Institute in Hamburg in 2000; this data center is responsible for the collection of data from all the EARLINET stations and provision of access to the data through a web interface.

The EARLINET data set covers the time period from April 2000 until today. To keep a maximum of data available, measurements from the preceding project "Deutsches 
Lidarnetz", a nationwide German lidar network (1997-2000) (Bösenberg et al., 2001b), have been added to the EARLINET data set.

All lidar data in the database are stored in netCDF format. Additional metadata is also provided in the netCDF files.

User access to the database is realized using two different web pages. Logging in to the web page at http://data.earlinet.org enables data maintenance. This page is only accessible for EARLINET data providers. It allows the users to upload new data, edit its metadata, and to remove data sets. Read-only access to the database is realized through the web portal at http://access.earlinet.org/ EARLINET. Here EARLINET members as well as external users can search, download and plot information from the database.

\subsubsection{Database content}

The main information stored in the files of the EARLINET database is the vertical distribution of aerosol backscatter and aerosol extinction coefficients. The EARLINET database stores only quantitative information. Qualitative parameters like range-corrected signals or graphical quick looks are not available. This kind of qualitative information is made available through the EARLINET website in the case of specific events on request of end users as in the case of the Eyjafjallajökull volcanic eruption in 2010 (Pappalardo et al., 2013).

There are two types of files defined in the EARLINET database

- The backscatter files (b-files). These files contain at least a profile of the aerosol backscatter coefficient $\left(\mathrm{m}^{-1} \mathrm{sr}^{-1}\right)$ derived from the elastic backscatter signal. This backscatter profile may be accompanied by an extinction coefficient profile. This extinction coefficient profile is not necessarily derived from Raman measurements. Any other method to derive the extinction profile may be used here.

- The extinction files (e-files). These files contain vertical profiles of aerosol extinction coefficient $\left(\mathrm{m}^{-1}\right)$ and of aerosol backscatter coefficients retrieved independently from Raman lidars without a priori assumptions on the existing relationship between them. Also, extinction coefficient profiles derived from high spectral resolution lidars are included here.

Additionally to backscatter and extinction coefficient profiles (and their statistical errors), there are more optional variables defined in the EARLINET format specification. These variables may be included in the b- (or e-) files. Among these parameters are the lidar ratio, the particle linear depolarization ratio, and the water vapor mixing ratio profiles. Whenever available, these variables are accompanied by the corresponding error estimate. An example of primary EARLINET data from a core station (multiwavelength Raman lidar) is given in Fig. 5.

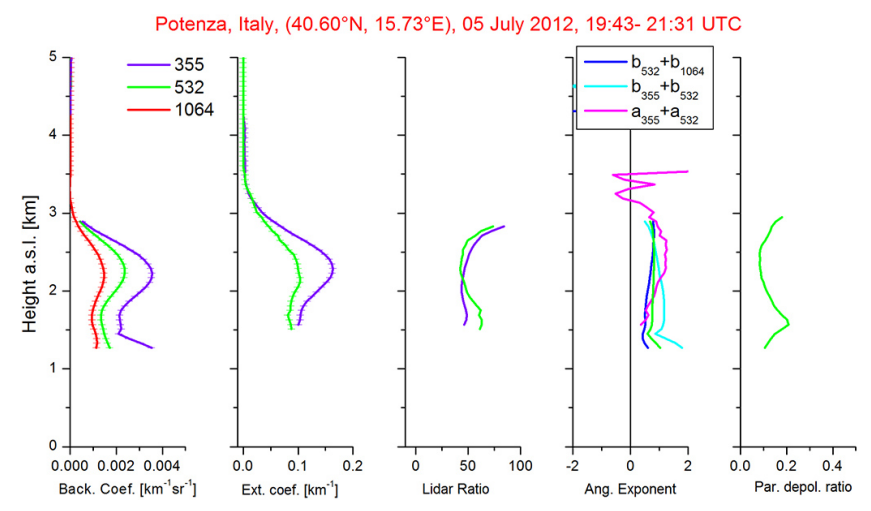

Figure 5. Example of aerosol optical properties vertical profiles retrieved by a an EARLINET core station. The error bars report the statistical error on the retrieved properties.

Each file in the EARLINET database can be assigned to one or more special groups of files (categories). This categorization can be used in the data selection to limit the access to a subset of files covering a specific event. The categories currently used in the database are the following: cirrus, climatology, diurnal cycles, volcanic eruptions, forest fires, photo smog, rural or urban, Saharan dust, stratosphere, and CALIPSO.

\subsubsection{Data publication scheme}

EARLINET follows a very simple scheme for publication of data. This scheme only consists of three levels of data visibility.

1. The first level of data access is reached by just uploading new data to the central database. These data should be uploaded to the database within three months after measurement. All EARLINET members can access these data immediately. These data are not visible to the public.

2. In the next step, the data are made public. All new data should be made accessible to the public as soon as possible and at the latest one year after the measurement. These "public" data become visible to registered external users who signed the "EARLINET data usage policy" agreement available at www.earlinet.org.

3. In the last step, the data are published in biannual volumes at the World Data Center for Climate (WDCC). For this, an approval process is applied to the data within 2 years after measurement. Data not passing this approval process are corrected in cooperation with the provider. Publication of the data and assignment of a digital object identifier (DOI) to the volumes makes them citable. This process also guaranties the permanent accessibility of the published data from the WDCC as a second source. The first volumes of the EARLINET 


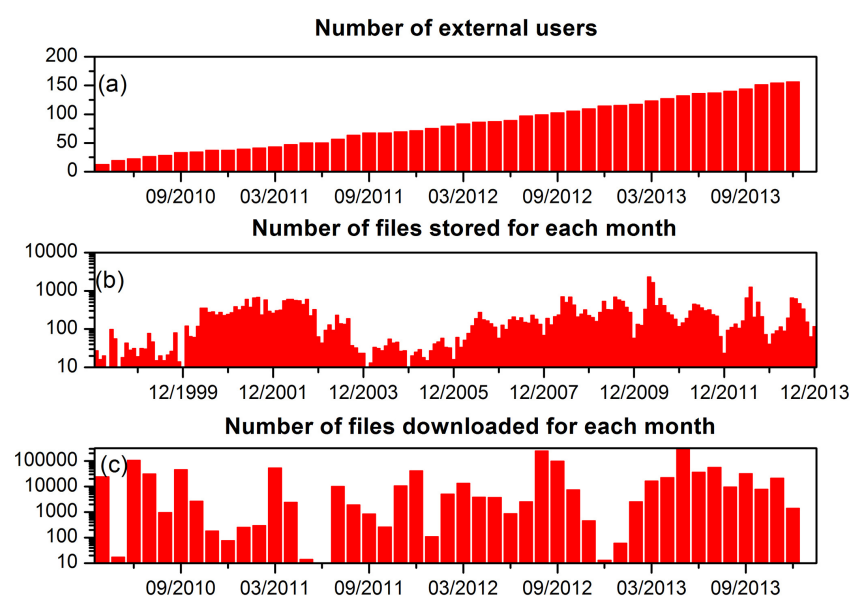

Figure 6. EARLINET database: number of registered external users (a); number of files uploaded to the database as of 31 December 2013 (b); number of files downloaded from the EARLINET database (c). Public access to the database, through the user web interface, started in April 2010.

database have been published at the WDCC (The EARLINET publishing group 2000-2010, 2014a, b, c, d, e).

\subsubsection{User access}

EARLINET members as well as external users get access to the database through a web interface. This web portal is accessible through a corresponding link on the EARLINET web page (www.earlinet.org) or directly through the link to http://access.earlinet.org/EARLINET. The access to this page is restricted and a username and password are required for login.

External users are required to (self-) register with the database system. The user has to sign the "EARLINET data usage policy" before access is granted. External users have access to all public data according to the data publication scheme. Access to the database, through the user web interface, has been opened in April 2010. Since then a slowly but steadily increasing number of users has registered for data access, as can be seen from Fig. 6a.

The system also provides a "search" form which allows entering search criteria to select a subset of data from the database, e.g., Saharan dust outbreaks, and plotting capabilities.

In addition to the data access at the EARLINET database, the public EARLINET data are also available through the ACTRIS data center at www.actris.net. Access to EARLINET data is also possible at the CERA database, the Climate and Environmental Retrieval and Archive of the WDCC, at http://cera-www.dkrz.de/WDCC/ui/Index.jsp.

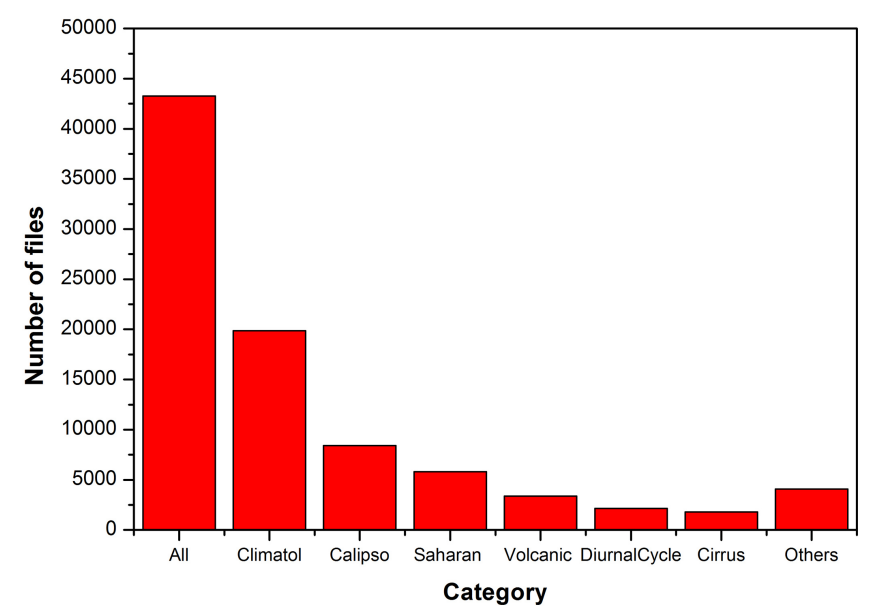

Figure 7. EARLINET database: distribution of data files in the different categories: climatology, CALIPSO, Saharan dust, volcanic eruptions, diurnal cycles, cirrus, and others (forest fires, photo smog, rural or urban, and stratosphere).

\subsubsection{Database status}

The EARLINET database represents the largest collection of ground-based data of the vertical aerosol distribution on a continental scale. The database holds measurements performed by 30 groups since January 1998. Some of these groups are not active members of EARLINET anymore. Nevertheless, all data uploaded once are kept in the database.

From the beginning of the systematic collection of data from coordinated lidar measurements a total of 43150 files (Fig. 6b) has been uploaded to the database. The very high number of files covering the period April/May 2010 is due to the almost continuous observation of the volcanic outbreak of the Eyjafjallajökull volcano in Iceland by nearly all stations of the network. Since April 2010 when the user web portal was made accessible to the public, more than 1.2 million files have been downloaded from the database (Fig. 6c).

Most of the files available from the database have been assigned to at least one category. These categories assign the measurements to a bigger data set. Figure 7 reports the distribution of the EARLINET data files for the different categories. The climatological category is the most populated category, with 19855 data files corresponding to the systematic observations. The CALIPSO and Saharan dust categories are also well populated (8418 and 5808 data files, respectively). EARLINET correlative data for CALIPSO, together with the differences with corresponding CALIPSO level-2 layer and profile products, have also been collected in a specific relational database available at www.earlinet.org (Pappalardo et al., 2010; Wandinger et al., 2011). 3387 data files belong to the volcanic category; most of them are related to the Eyjafjallajökull volcano eruption in April/May 2010. EARLINET specific geometrical and optical properties related to the Eyjafjallajökull eruption are collected in a 
specific relational database, available at www.earlinet.org, which provides the volcanic mask over Europe for the whole event (Pappalardo et al., 2013). Data files are also assigned to other categories: forest fires (1076 files), photosmog (112 files), urban or rural (2078 files), and stratosphere (820 files), which are also all reported together in category "Others" in Fig. 7.

\subsection{Contribution to other networks and programs}

A further important pillar of EARLINET is its cooperation with other observing networks and European and international programs. This cooperation will certainly increase with time; some examples of the present state shall be briefly outlined in the following paragraphs.

Synergies with AERONET, using the collocation of most of the EARLINET stations with AERONET, have been exploited for the retrieval of aerosol microphysical properties as discussed in detail in Müller et al. (2003), Ansmann et al. (2001, 2012), Wagner et al. (2013), Lopatin et al. (2013), Granados-Muñoz et al. (2014), Mamouri and Ansmann (2014), Chaikovsky et al. (2014), and Binietoglou et al. (2014).

EARLINET is a contributing network to GAW, the Global Atmosphere Watch program of the World Meteorological Organization (WMO) (www.wmo.int/pages/prog/arep/gaw/ aerosol.html), and within this program it strongly contributes to the implementation of GALION, the GAW Aerosol Lidar Observation Network (WMO, 2007, 2012). The specific objective of GALION is to provide the vertical component of the aerosol distribution through the coordination of existing lidar networks: the Latin American Lidar Network (ALINE), Latin America; the Asian Dust and Aerosol Lidar Observation Network (AD-Net), East Asia; Commonwealth of Independent States LIdar NETwork (CIS-LINET), Belarus, Russia, and Kyrgyz Republic; the Canadian Operational Research Aerosol Lidar Network (CORALNet), Canada; the European Aerosol Research Lidar Network (EARLINET), Europe; Network for the Detection of Atmospheric Composition Change (NDACC), Global; Center of Excellence in Remote Sensing Science and Technology (CREST) Lidar Network (CLN), eastern North America; the MicroPulse Lidar NETwork (MPLNET), Global.

Another example of a WMO-cooperation is the contribution to the WMO Sand and Dust Storm Warning Advisory and Assessment System (SDS-WAS) (www.wmo.int/ pages/prog/arep/wwrp/new/Sand_and_Dust_Storm.html).

Here, EARLINET is providing profiling of aerosol optical properties during Saharan dust outbreaks for dust model verification. In particular, a quantitative systematic comparison between measured and modeled profiles at network level is currently in progress.

Furthermore, EARLINET is involved in the exploitation of the recently established networks of ceilometers, mainly operated by national weather services. Ceilometers are simple one-wavelength eye-safe backscatter lidars operating continuously and unattended. They were primarily designed for the height assignment of clouds only, but currently their capability for providing aerosol information is under discussion (Flentje et al., 2010; Heese et al., 2010; Wiegner and Geiß, 2012), in particular after the Eyjafjallajökull eruption in 2010. EARLINET can serve as a benchmark to quantitatively assess the potential of such secondary networks, can demonstrate their benefits and the limitations, and work out strategies of synergism (Wiegner et al., 2014). In particular, advanced EARLINET lidars can be used to calibrate ceilometers. It is of special interest to what extent the aerosol characterization at the few EARLINET core stations can be "interpolated" by means of ceilometers, taking into account the limited information content of their products. This will, e.g., be of significant relevance for air traffic in the case of future volcanic eruptions. In this context, EARLINET is working closely with European Meteorological Services Network (EUMETNET) (www.eumetnet.eu) to support and contribute to the preparation of future community research in the field of robustness of the air transport system when faced with major weather hazards, in particular volcanic ash and ice.

EARLINET provides important support for ongoing and future satellite missions. Systematic observations within EARLINET, in particular when combined with aerosol transport models, can help to reduce or avoid the errors due to aerosol interference with the atmospheric optical parameters. Passive optical remote sensing from space is also used to derive aerosol parameters on a global scale. However, these retrievals are severely underdetermined so that a priori knowledge or assumptions about aerosol properties must be used. In this context EARLINET observations can be used to assess the performance of these retrievals, to identify the problems, and thus to improve the methodology and for this reason EARLINET cooperates with the most important space agencies (i.e., ESA, NASA, JAXA).

Since 2011 EARLINET has been integrated into ACTRIS, which is a European Project aiming at integrating European ground-based stations equipped with advanced atmospheric probing instrumentation for aerosols, clouds, and short-lived gas-phase species. ACTRIS is building the next generation of the ground-based component of the EU observing system by integrating three existing research infrastructures European Supersites for Atmospheric Aerosol Research (EUSAAR) (www.eusaar.net, for in situ aerosol observations), EARLINET, CLOUDNET (www.cloud-net.org, for cloud profiling), and a new trace gas network component into a single coordinated framework.

\section{Main EARLINET outcomes}

Thirteen years of EARLINET operation have provided a data set that has been widely used for aerosol climatological studies, for studies of specific events as Saharan dust 
intrusions and spread of volcanic ash plumes, and for the validation of aerosol data retrieved from spaceborne missions.

The spatiotemporal distribution of aerosols on a continental scale provided by EARLINET contributes to the quantification of anthropogenic and biogenic emissions and concentrations of aerosols, quantification of their budgets, radiative properties, and prediction of future trends. EARLINET contributes, therefore, to the improvement of the understanding of physical and chemical processes related to aerosols, their long-range transport and deposition, and their interaction with clouds (e.g., Guibert et al., 2005; Meier et al., 2012).

In the following, a brief overview of selected studies with a significant contribution from EARLINET is presented. A complete list of publications related to all the specific EARLINET activities is available at www.earlinet.org.

EARLINET data have been used for a first statistical range-resolved analysis of aerosol optical properties over Europe (Matthias et al., 2004b), climatological studies (Amiridis et al., 2005; De Tomasi et al., 2006; Giannakaki et al., 2010; Mattis et al., 2004, 2008; Wandinger et al., 2004; Navas-Guzmán et al., 2013a; Preißler et al., 2013), longrange transport analysis (Ansmann et al., 2003; Damoah et al., 2004; Papayannis et al., 2008; Wang et al., 2008; Sawamura et al., 2012; Pappalardo et al., 2013; Mattis et al., 2010), aerosol characterization, and implication of dust in weather forecast modeling (Pérez et al., 2006a). Moreover, retrieval algorithms for aerosol microphysical properties were developed and tested extensively with synthetic data and with real multiwavelength lidar data (e.g., Veselovskii et al., 2002, Müller et al., 2004, 2005; Böckmann et al., 2005; Tesche et al., 2008; Balis et al., 2010; Alados-Arboledas et al., 2011; Gasteiger et al., 2011; Mamouri et al., 2012; Wagner et al., 2013; Navas-Guzmán et al., 2013b). In many of these studies, lidar data were used for long-term monitoring of aerosol optical properties relevant for the Earth's radiation budget. In particular, the variability and the distribution of the most important aerosol parameters such as extinction and backscatter coefficient, lidar ratio, optical depth, linear depolarization ratio, and Angström coefficient, were studied. Their annual and seasonal cycles were investigated allowing the comprehension of the role played by the different orography of the EARLINET stations (e.g., Matthias and Bösenberg, 2002; Matthias et al., 2004b; De Tomasi et al., 2006). Moreover, studies of the correlation between measured lidar ratio values and the origin and path of the air masses on the basis of the backward trajectory analysis have been performed (e.g., Amiridis et al., 2005; Müller et al., 2007a, b; Giannakaki et al., 2010).

Based on the capability of (multiwavelengths) Raman lidars to retrieve intensive aerosol properties, i.e., the lidar ratio, the linear depolarization ratio, and Angström exponents, EARLINET constitutes an excellent basis for distinguishing different aerosol types. Examples of the corresponding approaches of "aerosol typing" can be found in, e.g., Müller et al. (2007a, b); and Groß et al. (2011b). In particular, discriminating between dust aerosols and volcanic ash is urgently needed for aviation.

Beside climatological measurements, EARLINET also performs specific observations during special events such as Saharan dust outbreaks (e.g., Ansmann et al., 2003; Balis et al., 2004; Mona et al., 2006; Papayannis et al., 2008; Guerrero-Rascado et al., 2009; Wiegner et al., 2011), volcanic eruptions (e.g., Pappalardo et al., 2004b, 2013; Wang et al., 2008; Ansmann et al., 2010; Groß et al., 2011a; Wiegner et al., 2012; Navas-Guzmán et al., 2013b), and biomass burning (e.g., Alados-Arboledas et al., 2011, Amiridis et al., 2009, Müller et al., 2007b, Balis et al., 2003; Mattis et al., 2003). In particular, within the network, an alert service for Saharan dust outbreaks has been established based on the use of operational dust forecasting of different regional models, such as the Skiron (Nickovic et al., 2001) and BSCDREAM8b (Barcelona Supercomputing Center - Dust Regional Atmospheric Model) models (Pérez et al., 2006b, c; Basart et al., 2012). Backward trajectories derived from operational weather prediction models and provided by the German Weather Service are used to characterize the history of the observed air parcels, accounting explicitly for the vertical distribution. EARLINET long-term observations of Saharan dust events over Europe performed from May 2000 permit the investigation of dust modification processes during transport over the continent through suitable case studies involving several stations around Europe (e.g., Ansmann et al., 2003), and they represent a unique tool for Saharan dust climatological studies on a continental scale. A first study on the impact of Saharan dust on European aerosol content has been performed on the basis of all EARLINET data acquired during the first period of operation of the network (2000 2002) (Papayannis et al., 2008), documenting the horizontal and vertical extent of dust outbreaks over Europe. This long-term database is a unique tool for a systematic comparison with dust model outputs. A methodology for a comparison of lidar measurements vs. model outputs and first results related to EARLINET observations in Potenza and BSC-DREAM8b-modeled profiles are reported in Mona et al. (2012).

Further EARLINET observations are devoted to monitor volcanic eruptions. During eruptions that occurred in 2001 and 2002, volcanic aerosol emitted from Etna was observed by EARLINET lidar stations (Pappalardo et al., 2004b; Wang et al., 2008; Villani et al., 2006).

A study of long-range transport of aerosol of volcanic origin over central Europe has been done for the period 2008 2010, related to eruptions of different volcanoes on the Aleutian Islands, Kamchatka, Alaska, and on the Kuril Islands (Mattis et al., 2010). Another long-range transport event of volcanic aerosols was studied for the Nabro eruption in 2011 (Sawamura et al., 2012). 
The most intensive period of EARLINET measurements related to a volcanic eruption is without any doubt the Eyjafjallajökull eruption in 2010. The EARLINET-coordinated observations and a methodology (Mona et al., 2012), specifically designed ad hoc for this event, provided a detailed description of the four-dimensional distribution of the volcanic cloud over Europe for the whole event from April-May 2010 (Pappalardo et al., 2013). The derivation of mass concentration as the most relevant property for air safety issues, using data of advanced EARLINET-type lidars and sun photometers, was covered in detail by Ansmann et al. (2011), Gasteiger et al. (2011), and Sicard et al. (2012). Furthermore, EARLINET lidar observations were successfully used to validate chemistry transport model results (Wiegner et al., 2012). The results of the four-dimensional distribution of the volcanic cloud are reported in a specific relational database available on request through the EARLINET website. Quantitative optical data collected by EARLINET for this event, including the specific relational database related to the geometrical properties of the volcanic cloud, represent a unique database for model evaluation, data validation, and integration.

EARLINET long-term observations of aerosol optical properties profiles are important for comparison and integration studies with satellite-borne passive measurements (van Gijsel et al., 2011). In particular, comparisons in terms of AOD of EARLINET (state-of-the-art data) vs. Moderate Resolution Imaging Spectroradiometer (MODIS) (data currently used as reference for assessing aerosol effects) also permit the investigation of EARLINET measurement scheduling representativeness.

EARLINET plays an important role in the validation and in the full exploitation of the lidar data that the space mission NASA CNES CALIPSO has been providing continuously since April 2006. EARLINET started correlative measurements for CALIPSO in June 2006. Correlative data have been used for investigating performances of CALIPSO (Mona et al., 2009; Wandinger et al., 2010). First EARLINETCALIPSO-combined studies on the representativeness of aerosol optical properties profiles were carried out (Pappalardo et al. 2010; Wandinger et al., 2011). Moreover, EARLINET climatological values of the lidar ratio and methods for the discrimination of dust in lidar measurements using depolarization information (Tesche et al., 2009) have been used to provide optimized dust products from CALIPSO observations (Amiridis et al., 2013).

\section{Summary and outlook}

Aerosols play a key role in many atmospheric processes governing, e.g., the atmospheric radiation budget, water cycle, and chemistry, which in turn affect human health, traffic systems, and the development of ecosystems. Thus, it is necessary to improve observational capabilities for aerosol distribution and their properties. It is undoubted that information on the vertical distribution is particularly important and that lidar remote sensing is the most appropriate tool for providing this information. Multiwavelength backscatter and extinction coefficient profiles are available from EARLINET by means of an easily accessible database, covering the $\mathrm{Eu}-$ ropean continent and 13 years of measurements.

In the last 10 years, significant technological improvements of lasers, and as well as optical and electronic components, have contributed to a much wider use of lidar technologies for aerosol monitoring and detailed studies on the role of atmospheric aerosols. There is an increasing demand for profiling data from modelers and from operational communities, for climatological studies, for air quality, but also for the observation of specific events related to atmospheric hazards, such as volcanic eruption and dust outbreaks. EARLINET has contributed significantly to these developments, setting the standards for instruments, methodology, and organization in this specific area.

In particular, thanks to recent optimization of instruments, data processing schemes, and strict quality assurance, EARLINET is evolving towards a more advanced and sustainable observing system, resulting in an increase of the observing capability (more stations and more advanced lidar instruments) and a reduction of costs of operations (best technical solutions, sustainable quality assurance strategies, and data processing). As a consequence, the EARLINET database will include a series of further aerosol parameters, and the extent of the database can grow faster than before.

The network provides important support for ongoing and future satellite missions. At present, EARLINET is continuing correlative measurements for CALIPSO and it will also contribute to future satellite missions with lidar instrumentation onboard, such as the ESA Explorer missions Atmospheric Dynamics Mission - Aeolus (ADM-Aeolus) (Stoffelen et al., 2005) and Earth Clouds, Aerosols and Radiation Explorer (EarthCARE) (European Space Agency, 2004; Illingworth et al., 2014). Both missions will involve a High Spectral Resolution Lidar at $355 \mathrm{~nm}$, able to give independent measurements of aerosol extinction and backscatter coefficient in the UV. The multiwavelength EARLINET data will be very useful for the validation of these missions, providing the conversion factors that allow us to link the aerosol data at $532 \mathrm{~nm}$ and $1064 \mathrm{~nm}$ from CALIPSO with the data at $355 \mathrm{~nm}$ from ADM-Aeolus and EarthCARE for a consistent long-term global data set. In addition, EARLINET will play a crucial role in the validation of further upcoming missions for operational satellites, in particular Sentinel-4 (Ingmann et al., 2012) (in geostationary orbit) and Sentinel-5 (Ingmann et al., 2012) (low earth orbit), which will be deployed within the framework of Copernicus (www.copernicus.eu).

The future availability of EARLINET near-real-time vertical profiles will be an important step for the assimilation of lidar data into models and will result in a strong contribution to the Copernicus program and to the WMO SDS-WAS. 
EARLINET is now a reference network and represents the forum of lidar experts in Europe for the development of new lidar technologies, retrieval software, and methodologies for aerosol study. It will continue to contribute to the improvement of continuous observations and methodological developments that are urgently needed to provide the multi-year continental-scale data set necessary to assess the impact of aerosols on the European and global environment, to detect trends, and to support future satellite missions. This will be done, even more in the future, in cooperation with the modeling community and the operational community; this is the direction which future planned developments of the network will take in order to extend the lidar measurements towards more continuous observations and near-real-time data delivery.

EARLINET is a key component of the ACTRIS infrastructure, which represents a big step towards a better coordination of the atmospheric observations in Europe towards the establishment of the European component of an Integrated Atmospheric Global System as part of GEOSS, the Global Earth Observation System of Systems (GEOSS, 2005).

Acknowledgements. The financial support for EARLINET by the European Union under grant RICA 025991 in the Sixth Framework Programme is gratefully acknowledged. Since 2011, EARLINET has been integrated into the ACTRIS Research Infrastructure project, supported by the European Union Seventh Framework Programme (fp7/2007-2013) under grant agreement no. 262254. The financial support within the framework of the EU FP7 project WEZARD (Weather Hazards for Aeronautics), grant agreement no: 285050 , is also acknowledged.

The authors acknowledge the ESA financial support under the ESRIN contracts 21769/08/I-OL and 22202/09/I-EC and the ESTEC contracts 21487/08/NL/HE and 4000104106/11/NL/FF/fk.

Edited by: R. Ferrare

\section{References}

Alados-Arboledas, L., Müller, D., Guerrero-Rascado, J. L., NavasGuzmán, F., Pérez- Ramírez, D., and Olmo, F. J.: Optical and microphysical properties of fresh biomass burning aerosol retrieved by Raman lidar, and star-and sun-photometry, Geophys. Res. Lett., 38, L01807, doi:10.1029/2010GL045999, 2011.

Amiridis, V., Balis, D., Kazadzis, S., Bais, A., Giannakaki, E., Papayannis, A., and Zerefos, C.: Four years aerosol observations with a Raman lidar at Thessaloniki, Greece in the framework of EARLINET, J. Geophys. Res., 110, D21203, doi:10.1029/2005JD006190, 2005.

Amiridis, V., Balis, D. S., Giannakaki, E., Stohl, A., Kazadzis, S., Koukouli, M. E., and Zanis, P.: Optical characteristics of biomass burning aerosols over Southeastern Europe determined from UVRaman lidar measurements, Atmos. Chem. Phys., 9, 2431-2440, doi:10.5194/acp-9-2431-2009, 2009.

Amiridis, V., Wandinger, U., Marinou, E., Giannakaki, E., Tsekeri, A., Basart, S., Kazadzis, S., Gkikas, A., Taylor, M., Baldasano, J., and Ansmann, A.: Optimizing CALIPSO Saharan dust retrievals, Atmos. Chem. Phys., 13, 12089-12106, doi:10.5194/acp-1312089-2013, 2013.

Amodeo, A., Mattis, I., Böckmann, C., D’Amico, G., Müller, D., Osterloh, L., Chaikovsky, A., Pappalardo, G., Ansmann, A., Apituley, A., Alados-Arboledas, L., Balis, D., Comeron, A., Freudenthaler, V., Mitev, V., Nicolae, D., Papayannis, A., Perrone, M. R., Pietruczuk, A., Pujadas, M., Putaud, J., Ravetta, F., Rizi, V., Simeonov, V., Spinelli, N., Stebel, K., Stoyanov, D., Trickl, T., and Wiegner, M.: Optimization of lidar data processing: a goal of the EARLINETASOS project, in: Lidar Technologies, Techniques, and Measurements for Atmospheric Remote Sensing III, edited by: Singh, U. N. and Pappalardo, G., Proceedings of SPIE, 6750, 67500F, doi:10.1117/12.738348, 2007.

Amodeo, A., D’Amico, G., Mattis, I., and Freudenthaler, V.: Error calculation for EARLINET products in the context of quality assurance and single calculus chain, Atmos. Meas. Tech. Discuss., in preparation, 2014.

Ansmann, A., Riebesell, M., and Weitkamp, C.: Measurement of atmospheric aerosol extinction profiles with a Raman lidar, Opt. Lett., 15, 746-748, 1990.

Ansmann, A., Wandinger, U., Riebesell, M., Weitkamp, C., and Michaelis, W.: Independent measurement of extinction and backscatter profiles in cirrus clouds by using a combined Raman elastic-backscatter lidar, Appl. Optics, 31, 7113-7131, 1992.

Ansmann, A., Bösenberg, J., Chaikovsky, A., Comerón, A., Eckhardt, S., Eixmann, R., Freudenthaler, V., Ginoux, P., Komguem, P., Linné, H., Ángel López Márquez, M., Matthias, V., Mattis, I., Mitev, V., Müller, D., Music, S., Nickovic, S., Pelon, J., Sauvage, L., Sobolewsky, P., Srivastava, M. K., Stohl, A., Torres, O., Vaughan, G., Wandinger, U., and Wiegner, M.: Long range transport of Saharan dust to northern Europe: the 11-16 October 2001 outbreak with EARLINET, J. Geophys. Res., 108, 4783, doi:10.1029/2003JD003757, 2003.

Ansmann, A., Tesche, M., Groß, S., Freudenthaler, V., Seifert, P., Hiebsch, A., Schmidt, J., Wandinger, U., Mattis, I., Müller, D., and Wiegner, M.: The 16 April 2010 major volcanic ash plume over central Europe: EARLINET lidar and AERONET photometer observations at Leipzig and Munich, Germany, Geophys. Res. Lett., 37, L13810, doi:10.1029/2010GL043809, 2010.

Ansmann, A., Tesche, M., Seifert, P. Groß, S., Freudenthaler, V., Apituley, A., Wilson, K. M., Serikov, I., Linné, H., Heinold, B., Hiebsch, A., Schnell, F., Schmidt, J., Mattis, I., Wandinger, U., and Wiegner, M.: Ash and fine-mode particle mass profiles from EARLINET-AERONET observations over central Europe after the eruptions of the Eyjafjallajökull volcano in 2010, J. Geophys. Res., 116, D00U02, doi:10.1029/2010JD015567, 2011.

Ansmann, A., Seifert, P., Tesche, M., and Wandinger, U.: Profiling of fine and coarse particle mass: case studies of Saharan dust and Eyjafjallajökull/Grimsvötn volcanic plumes, Atmos. Chem. Phys., 12, 9399-9415, doi:10.5194/acp-12-9399-2012, 2012.

Apituley, A., Serikov, I., Linné, H., and Freudenthaler, V.: EARLINET Concepts for Large Dynamic Range Aerosol Lidars, Atmos. Meas. Tech. Discuss., in preparation, 2014.

Balis, D. S., Amiridis, V., Zerefos, C., Gerasopoulos, E., Andreae, M., Zanis, P., Kazantzidis, A., Kazadzis, S., and Papayannis, A.: Raman lidar and sun photometric measurements of aerosol optical properties over Thessaloniki, Greece during a biomass burning episode, Atmos. Environ., 37, 4529-4538, 2003. 
Balis, D. S., Amiridis, V., Nickovic, S., Papayannis, A., and Zerefos, C.: Optical properties of Saharan dust layers as detected by a Raman lidar at Thessaloniki, Greece, Geophys. Res. Lett., 31, L13104, doi:10.1029/2004GL019881, 2004.

Balis, D., Giannakaki, E., Müller, D., Amiridis, V., Kelektsoglou, K., Rapsomanikis, S., and Bais, A.: Estimation of the microphysical aerosol properties over Thessaloniki, Greece, during the SCOUT-O3 campaign with the synergy of Raman lidar and Sun photometer data, J. Geophys. Res., 115, D08202, doi:10.1029/2009JD013088, 2010.

Basart, S., Pérez, C., Nickovic, S., Cuevas, E., Schulz, M., and Baldasano, J. M.: Development and evaluation of BSCDREAM8b dust regional model over Northern Africa, the Mediterranean and the Middle East regions, Tellus B, 64, 18539, doi:10.3402/tellusb.v64i0.18539, 2012.

Belegante, L., Bravo-Aranda, J. A., Freudenthaler, V., Nicolae, D., Alados-Arboledas, A., Amodeo, A., D’Amico, G., Engelmann, R., Kokkalis, P., Papayannis, A., and Wandinger, U.: Experimental assessment of the lidar polarizing sensitivity, Atmos. Meas. Tech. Discuss., in preparation, 2014.

Binietoglou, I., Terradellas, E., Alados-Arboledas, L., Argyrouli, A., Baldasano, J. M., Balis, D., Basart, S., Chaikovsky, A., Comeron, A., D’Amico, G., Granados-Munoz, M. J., Kokkalis, P., Nicolae, D., Nikcovic, S., Papayannis, A., Pappalardo, G., Pereira, S. N., Perrone, M. R., Posyniak, M., Sicard, M., Siomos, N., Talianu, C., Wagner, J., and Wandinger, U.: Application of the Lidar/photometer algorithm: dust model evaluation, Atmos. Meas. Tech. Discuss., in preparation, 2014.

Böckman, C., Wandinger, U., Ansmann, A., Bösenberg, J., Amiridis, V., Boselli, A., Delaval, A., De Tomasi, F., Frioud, M., Hågård, A., Horvat, M., Iarlori, M., Komguem, L. Kreipl, S., Larchevêque, G., Matthias, V., Papayannis, A., Pappalardo, G., Rocadembosch, F., Rodriguez, J. A., Schneider, J., Shcherbakov, V., and Wiegner, M.: Aerosol lidar intercomparison in the framework of the EARLINET project. 2. Aerosol backscatter algorithms, Appl. Optics, 43, 977-989, 2004.

Böckmann, C., Mironova, I., Müller, D., Schneidenbach, L., and Nessler, R.: Microphysical aerosol parameters from multiwavelength lidar, J. Opt. Soc. Am. A, 22, 518-528, doi:10.1364/JOSAA.22.000518, 2005.

Bösenberg, J., Ansmann, A., Baldasano, J. M., Balis, D., Böckmann, C., Calpini, B., Chaikovsky, A., Flamant, P., Hagard, A., Mitev, V., Papayannis, A., Pelon, J., Resendes, D., Schneider, J., Spinelli, N., Trickl, T., Vaughan, G., Visconti, G., and Wiegner, M.: EARLINET: a European Aerosol Research Lidar Network, in: Advances in Laser Remote Sensing, edited by: Dabas, A., Loth, C., and Pelon, J., Ecole polytechnique, Palaiseau Cedex, France, 155-158, 2001a.

Bösenberg, J., Alpers, M., Althause, D., Ansmann, A., Böckmann, C., Eixmann, R., Franke, A., Freudenthaler, V., Giehl, H., Jäger, H., Kreipl, S., Linné, H., Matthias, V., Mattis, I., Müller, D., Sarközi, J., Schneidenbach, L., Schneider, J., Trickl, T., Vorobieva, E., Wandinger, U., and Wiegner, M.: The German Aerosol Lidar Network: methodology, Data, Analysis, MaxPlanck-Reports 317, available at: http://www.mpimet.mpg.de/ fileadmin/publikationen/Reports/max_scirep_317.pdf (last access: 19 March 2014), 2001b.

Bösenberg, J., Matthias, V., Amodeo, A., Amoiridis, V., Ansmann, A., Baldasano, J. M., Balin, I., Balis, D., Böckmann, C., Boselli,
A., Carlsson, G., Chaikovsky, A., Chourdakis, G., Comeron, A., De Tomasi, F., Eixmann, R., Freudenthaler, V., Giehl, H., Grigorov, I., Hågård, A., Iarlori, M., Kirsche, A., Kolarov, G., Komguem, L., Kreipl, S., Kumpf, S., Larchevêque, G., Linné, H., Matthey, R., Mattis, I., Mekler, A., Mironova, I., Mitev, V., Mona, L., Müller, D., Music, S., Nickovic, S., Pandolfi, M., Papayannis, A., Pappalardo, G., Pelon, J., Pérez, C., Perrone, M. R., Persson, R., Resendes, D. P., Rizi, V., Rocadenbosch, F., Rodrigues, J. A., Sauvage, L., Schneidenbach, L., Schumacher, R., Shcherbakov, V., Simeonov, V., Sobolewski, P., Spinelli, N., Stachlewska, I., Stoyanov, D., Trickl, T., Tsaknakis, G., Vaughan, G., Wandinger, U., Wang, X., Wiegner, M., Zavrtanik, M., and Zerefos, C.: EARLINET: a European Aerosol Research Lidar Network to Establish an Aerosol Climatology, MPI-Report 348, Hamburg, 2003.

Boucher, O., Randall, D., Artaxo, P., Bretherton, C., Feingold, G., Forster, P., Kerminen, V.-M., Kondo, Y., Liao, H., Lohmann, U., Rasch, P., Satheesh, S. K., Sherwood, S., Stevens, B., and Zhang, X. Y.: Clouds and Aerosols. in: Climate Change 2013: The Physical Science Basis. Contribution of Working Group I to the Fifth Assessment Report of the Intergovernmental Panel on Climate Change, edited by: Stocker, T. F., Qin, D., Plattner, G.-K., Tignor, M., Allen, S. K., Boschung, J., Nauels, A., Xia, Y., Bex, V., and Midgley, P. M., Cambridge University Press, Cambridge, UK, New York, NY, USA, 2013.

Bravo-Aranda, J. A., Belegante, L., Freudenthaler, V., AladosArboledas, A., Nicolae, D., Amodeo, A., D'Amico, G., Engelmann, R., Kokkalis, P., Papayannis, A., and Wandinger, U.: Assessment of lidar depolarization uncertainties by means of lidar polarizing sensitivity simulator, Atmos. Meas. Tech. Discuss., in preparation, 2014.

Chaikovsky, A., Dubovik, O., Goloub, P., Tanré, D., Pappalardo, G., Wandinger, U., Chaikovsky, A., Denisov, D., Grudo, Y., Lopatsin, A., Karol, Y., Lapyonok, T., Amiridis, V., Ansmann, A., Apituley, A., Alados-Arboledas, L., Binietoglou, I., Freudenthaler, V., Kokkalis, P., Granados Muñoz, M. J., Nicolae, D., Papayannis, A., Perrone, M. R., Pietruczuk, A., Pisani, G., Rocadenbosch, F., Sicard, M., Talianu, C., De Tomasi, F., Tsekeri, A., Wagner, J., and Wang, X.: Algorithm and software package for the retrieval of vertical aerosol properties in the atmospheric column using combined lidar/photometer data, Atmos. Meas. Tech. Discuss., in preparation, 2014.

D’Amico, G., Amodeo, A., Mattis, I., Binietoglou, I., Baars, H., Freudenthaler, V., and Pappalardo, G.: EARLINET Single Calculus Chain - general presentation, methodology and strategy, Atmos. Meas. Tech. Discuss., in preparation, 2014a.

D’Amico, G., Amodeo, A., and Mattis, I.: Single Calculus Chain technical Part 1: Preprocessing of raw lidar data, Atmos. Meas. Tech. Discuss., in preparation, 2014b.

Damoah, R., Spichtinger, N., Forster, C., James, P., Mattis, I., Wandinger, U., Beirle, S., Wagner, T., and Stohl, A.: Around the world in 17 days - hemispheric-scale transport of forest fire smoke from Russia in May 2003, Atmos. Chem. Phys., 4, 13111321, doi:10.5194/acp-4-1311-2004, 2004.

De Tomasi, F., Tafuro, A. M., and Perrone, M. R.: Height and seasonal dependence of aerosol optical properties over south-east Italy, J. Geophys. Res., 111, D10203, doi:10.1029/2005JD006779, 2006.

The EARLINET publishing group 2000-2010: Adam, M., AladosArboledas, L., Althausen, D., Amiridis, V., Amodeo, A., Ans- 
mann, A., Apituley, A., Arshinov, Y., Balis, D., Belegante, L., Bobrovnikov, S., Boselli, A., Bravo-Aranda, J. A., Bösenberg, J., Carstea, E., Chaikovsky, A., Comerón, A., D’Amico, G., Daou, D., Dreischuh, T., Engelmann, R., Finger, F., Freudenthaler, V., Garcia-Vizcaino, D., García, A. J. F., Geiß, A., Giannakaki, E., Giehl, H., Giunta, A., de Graaf, M., GranadosMuñoz, M. J., Grein, M., Grigorov, I., Groß, S., Gruening, C., Guerrero-Rascado, J. L., Haeffelin, M., Hayek, T., Iarlori, M., Kanitz, T., Kokkalis, P., Linné, H., Madonna, F., Mamouriat, R.-E., Matthias, V., Mattis, I., Menéndez, F. M., Mitev, V., Mona, L., Morille, Y., Muñoz, C., Müller, A., Müller, D., Navas-Guzmán, F., Nemuc, A., Nicolae, D., Pandolfi, M., Papayannis, A., Pappalardo, G., Pelon, J., Perrone, M. R., Pietruczuk, A., Pisani, G., Potma, C., Preißler, J., Pujadas, M., Putaud, J., Radu, C., Ravetta, F., Reigert, A., Rizi, V., Rocadenbosch, F., Rodríguez, A., Sauvage, L., Schmidt, J., Schnell, F., Schwarz, A., Seifert, P., Serikov, I., Sicard, M., Silva, A. M., Simeonov, V., Siomos, N., Sirch, T., Spinelli, N., Stoyanov, D., Talianu, C., Tesche, M., De Tomasi, F., Trickl, T., Vaughan, G., Volten, H., Wagner, F., Wandinger, U., Wang, X., Wiegner, M., and Wilson, K. M.: EARLINET all observations (2000-2010), World Data Center for Climate (WDCC), doi:10.1594/WDCC/EN_all_measurements_2000-2010, 2014a.

The EARLINET publishing group 2000-2010: Adam, M., AladosArboledas, L., Althausen, D., Amiridis, V., Amodeo, A., Ansmann, A., Apituley, A., Arshinov, Y., Balis, D., Belegante, L., Bobrovnikov, S., Boselli, A., Bravo-Aranda, J. A., Bösenberg, J., Carstea, E., Chaikovsky, A., Comerón, A., D’Amico, G., Daou, D., Dreischuh, T., Engelmann, R., Finger, F., Freudenthaler, V., Garcia-Vizcaino, D., García, A. J. F., Geiß, A., Giannakaki, E., Giehl, H., Giunta, A., de Graaf, M., GranadosMuñoz, M. J., Grein, M., Grigorov, I., Groß, S., Gruening, C., Guerrero-Rascado, J. L., Haeffelin, M., Hayek, T., Iarlori, M., Kanitz, T., Kokkalis, P., Linné, H., Madonna, F., Mamouriat, R.E., Matthias, V., Mattis, I., Menéndez, F. M., Mitev, V., Mona, L., Morille, Y., Muñoz, C., Müller, A., Müller, D., Navas-Guzmán, F., Nemuc, A., Nicolae, D., Pandolfi, M., Papayannis, A., Pappalardo, G., Pelon, J., Perrone, M.R., Pietruczuk, A., Pisani, G., Potma, C., Preißler, J., Pujadas, M., Putaud, J., Radu, C., Ravetta, F., Reigert, A., Rizi, V., Rocadenbosch, F., Rodríguez, A., Sauvage, L., Schmidt, J., Schnell, F., Schwarz, A., Seifert, P., Serikov, I., Sicard, M., Silva, A. M., Simeonov, V., Siomos, N., Sirch, T., Spinelli, N., Stoyanov, D., Talianu, C., Tesche, M., De Tomasi, F., Trickl, T., Vaughan, G., Volten, H., Wagner, F., Wandinger, U., Wang, X., Wiegner, M., and Wilson, K. M.: EARLINET climatology (2000-2010), World Data Center for Climate (WDCC), doi:10.1594/WDCC/EN_Climatology_20002010, 2014b.

The EARLINET publishing group 2000-2010: Adam, M., AladosArboledas, L., Althausen, D., Amiridis, V., Amodeo, A., Ansmann, A., Apituley, A., Arshinov, Y., Balis, D., Belegante, L., Bobrovnikov, S., Boselli, A., Bravo-Aranda, J. A., Bösenberg, J., Carstea, E., Chaikovsky, A., Comerón, A., D’Amico, G., Daou, D., Dreischuh, T., Engelmann, R., Finger, F., Freudenthaler, V., Garcia-Vizcaino, D., García, A. J. F., Geiß, A., Giannakaki, E., Giehl, H., Giunta, A., de Graaf, M., GranadosMuñoz, M. J., Grein, M., Grigorov, I., Groß, S., Gruening, C., Guerrero-Rascado, J. L., Haeffelin, M., Hayek, T., Iarlori, M., Kanitz, T., Kokkalis, P., Linné, H., Madonna, F., Mamouriat,
R.-E., Matthias, V., Mattis, I., Menéndez, F. M., Mitev, V., Mona, L., Morille, Y., Muñoz, C., Müller, A., Müller, D., NavasGuzmán, F., Nemuc, A., Nicolae, D., Pandolfi, M., Papayannis, A., Pappalardo, G., Pelon, J., Perrone, M. R., Pietruczuk, A., Pisani, G., Potma, C., Preißler, J., Pujadas, M., Putaud, J., Radu, C., Ravetta, F., Reigert, A., Rizi, V., Rocadenbosch, F., Rodríguez, A., Sauvage, L., Schmidt, J., Schnell, F., Schwarz, A., Seifert, P., Serikov, I., Sicard, M., Silva, A. M., Simeonov, V., Siomos, N., Sirch, T., Spinelli, N., Stoyanov, D., Talianu, C., Tesche, M., De Tomasi, F., Trickl, T., Vaughan, G., Volten, H., Wagner, F., Wandinger, U., Wang, X., Wiegner, M., and Wilson, K. M.: EARLINET correlative observations for CALIPSO (2006-2010), World Data Center for Climate (WDCC), doi:10.1594/WDCC/EN_Calipso_2006-2010, 2014c.

The EARLINET publishing group 2000-2010, Adam, M., AladosArboledas, L., Althausen, D., Amiridis, V., Amodeo, A., Ansmann, A., Apituley, A., Arshinov, Y., Balis, D., Belegante, L., Bobrovnikov, S., Boselli, A., Bravo-Aranda, J. A., Bösenberg, J., Carstea, E., Chaikovsky, A., Comerón, A., D’Amico, G., Daou, D., Dreischuh, T., Engelmann, R., Finger, F., Freudenthaler, V., Garcia-Vizcaino, D., García, A. J. F., Geiß, A., Giannakaki, E., Giehl, H., Giunta, A., de Graaf, M., GranadosMuñoz, M. J., Grein, M., Grigorov, I., Groß, S., Gruening, C., Guerrero-Rascado, J. L., Haeffelin, M., Hayek, T., Iarlori, M., Kanitz, T., Kokkalis, P., Linné, H., Madonna, F., Mamouriat, R.-E., Matthias, V., Mattis, I., Menéndez, F. M., Mitev, V., Mona, L., Morille, Y., Muñoz, C., Müller, A., Müller, D., NavasGuzmán, F., Nemuc, A., Nicolae, D., Pandolfi, M., Papayannis, A., Pappalardo, G., Pelon, J., Perrone, M. R., Pietruczuk, A., Pisani, G., Potma, C., Preißler, J., Pujadas, M., Putaud, J., Radu, C., Ravetta, F., Reigert, A., Rizi, V., Rocadenbosch, F., Rodríguez, A., Sauvage, L., Schmidt, J., Schnell, F., Schwarz, A., Seifert, P., Serikov, I., Sicard, M., Silva, A. M., Simeonov, V., Siomos, N., Sirch, T., Spinelli, N., Stoyanov, D., Talianu, C., Tesche, M., De Tomasi, F., Trickl, T., Vaughan, G., Volten, H., Wagner, F., Wandinger, U., Wang, X., Wiegner, M., and Wilson, K. M.: EARLINET observations related to volcanic eruptions (2000-2010), World Data Center for Climate (WDCC), doi:10.1594/WDCC/EN_VolcanicEruption_2000-2010, 2014d.

The EARLINET publishing group 2000-2010: Adam, M., AladosArboledas, L., Althausen, D., Amiridis, V., Amodeo, A., Ansmann, A., Apituley, A., Arshinov, Y., Balis, D., Belegante, L., Bobrovnikov, S., Boselli, A., Bravo-Aranda, J. A., Bösenberg, J., Carstea, E., Chaikovsky, A., Comerón, A., D’Amico, G., Daou, D., Dreischuh, T., Engelmann, R., Finger, F., Freudenthaler, V., Garcia-Vizcaino, D., García, A. J. F., Geiß, A., Giannakaki, E., Giehl, H., Giunta, A., de Graaf, M., GranadosMuñoz, M. J., Grein, M., Grigorov, I., Groß, S., Gruening, C., Guerrero-Rascado, J. L., Haeffelin, M., Hayek, T., Iarlori, M., Kanitz, T., Kokkalis, P., Linné, H., Madonna, F., Mamouriat, R.-E., Matthias, V., Mattis, I., Menéndez, F. M., Mitev, V., Mona, L., Morille, Y., Muñoz, C., Müller, A., Müller, D., NavasGuzmán, F., Nemuc, A., Nicolae, D., Pandolfi, M., Papayannis, A., Pappalardo, G., Pelon, J., Perrone, M. R., Pietruczuk, A., Pisani, G., Potma, C., Preißler, J., Pujadas, M., Putaud, J., Radu, C., Ravetta, F., Reigert, A., Rizi, V., Rocadenbosch, F., Rodríguez, A., Sauvage, L., Schmidt, J., Schnell, F., Schwarz, A., Seifert, P., Serikov, I., Sicard, M., Silva, A. M., Simeonov, V., Siomos, N., Sirch, T., Spinelli, N., Stoyanov, D., Talianu, 
C., Tesche, M., De Tomasi, F., Trickl, T., Vaughan, G., Volten, H., Wagner, F., Wandinger, U., Wang, X., Wiegner, M., and Wilson, K. M.: EARLINET observations related to Saharan Dust events (2000-2010), World Data Center for Climate (WDCC), doi:10.1594/WDCC/EARLINET_SaharanDust_2000-2010, 2014e.

European Space Agency (ESA): Earth Clouds, Aerosols, and Radiation Explorer, ESA Technical report, SP-1279(1), ESTEC, Noordwijk, the Netherlands, 2004.

Flentje, H., Claude, H., Elste, T., Gilge, S., Köhler, U., PlassDülmer, C., Steinbrecht, W., Thomas, W., Werner, A., and Fricke, W.: The Eyjafjallajökull eruption in April 2010 - detection of volcanic plume using in-situ measurements, ozone sondes and lidar-ceilometer profiles, Atmos. Chem. Phys., 10, 10085-10092, doi:10.5194/acp-10-10085-2010, 2010.

Forster, P., Ramaswamy, V., Artaxo, P., Berntsen, T., Betts, R., Fahey, D. W., Haywood, J., Lean, J., Lowe, D. C., Myhre, G., Nganga, J., Prinn, R., Raga, G., Schulz, M., and Van Dorland, R.: Changes in Atmospheric Constituents and in Radiative Forcing, in: Climate Change 2007: The Physical Science Basis, Contribution of Working Group I to the Fourth Assessment Report of the Intergovernmental Panel on Climate Change, edited by: Solomon, S., Qin, D., Manning, M., Chen, Z., Marquis, M., Averyt, K. B., Tignor, M., and Miller, H. L., Cambridge University Press, Cambridge, United Kingdom and New York, NY, USA, available at: http://www.ipcc.ch/pdf/assessment-report/ar4/wg1/ ar4_wg1_full_report.pdf (last access: 19 March 2014), 2007.

Freudenthaler, V.: Polarization sensitivity of lidar systems and the $90^{\circ}$-calibration, Atmos. Meas. Tech. Discuss., in preparation, 2014.

Freudenthaler, V., Esselborn, M., Wiegner, M., Heese, B., Tesche, M., Ansmann, A., Müller, D., Althausen, D., Wirth, M., Andreas, F. I. X., Ehret, G., Knippertz, P., Toledano, C., Gasteiger, J., Garhammer, M., and Seefeldner, M.: Depolarization ratio profiling at several wavelengths in pure Saharan dust during SAMUM 2006, Tellus B, 61, 165-179, 2009.

Freudenthaler, V., Gross, S., Engelmann, R., Mattis, I., Wandinger, U., Pappalardo, G., Amodeo, A., Giunta, A., D’Amico, G., Chaikovsky, A., Osipenko, F., Slesar, A., Nicolae, D., Belegante, L., Talianu, C., Serikov, I., Linne, H., Jansen, F., Wilson, K., de Graaf, M., Apituley, A., Trickl, T., Giehl, H., and Adam, M.: EARLI09 - direct intercomparison of eleven EARLINET lidar systems, in: Proceedings of the 25th International Laser Radar Conference, St. Petersburg, Russia, 5-9 July, 891-894, 2010.

Freudenthaler, V., Linne, H., Chaikovski, A., Groß, S., and Rabus, D.: EARLINET lidar quality assurance tools, Atmos. Meas. Tech. Discuss., in preparation, 2014.

Gasteiger, J., Groß, S., Freudenthaler, V., and Wiegner, M.: Volcanic ash from Iceland over Munich: mass concentration retrieved from ground-based remote sensing measurements, Atmos. Chem. Phys., 11, 2209-2223, doi:10.5194/acp-11-22092011, 2011.

GEOSS: Global Earth Observation System of Systems GEOSS, 10Year implementation plan Reference document, Group on Earth observations, edited by: Battrick, B., ESA Publications Division, GEO 1000R, Noordwijk, the Netherlands, 2005.

Giannakaki, E., Balis, D. S., Amiridis, V., and Zerefos, C.: Optical properties of different aerosol types: seven years of combined Raman-elastic backscatter lidar measurements in Thessaloniki,
Greece, Atmos. Meas. Tech., 3, 569-578, doi:10.5194/amt-3569-2010, 2010.

Granados-Muñoz, M. J., Guerrero-Rascado, J. L., Bravo-Aranda, J. A., Navas-Guzmán, F., Valenzuela, A., Lyamani, H., Chaikovsky, A., Wandinger, U., Ansmann, A., Dubovik, O., Grudo, J., and Alados-Arboledas, L.: Retrieving aerosol microphysical properties by LIdar-Radiometer Inversion Code (LIRIC) for different aerosol types, J. Geophys. Res., 119, 4836-4858, doi:10.1002/2013JD021116, 2014.

Groß, S., Freudenthaler, V., Wiegner, M., Gasteiger, J., Geiß, A., and Schnell, F.: Dual-wavelength linear depolarization ratio of volcanic aerosols: lidar measurements of the Eyjafjallajökull plume over Maisach, Germany, Atmos. Environ., 48, 85-96, doi:10.1016/j.atmosenv.2011.06.017, 2011a.

Groß, S., Tesche, M., Freudenthaler, V., Toledano, C., Wiegner, M., Ansmann, A., Althausen, D., and Seefeldner, M.: Characterization of Saharan dust, marine aerosols and mixtures of biomass burning aerosols and dust by means of multi-wavelength depolarizationand Raman-measurements during SAMUM-2, Tellus B, 63, 706-724, doi:10.1111/j.1600- 0889.2011.00556.x, 2011b.

Guerrero-Rascado, J. L., Olmo, F. J., Avilés-Rodríguez, I., NavasGuzmán, F., Pérez- Ramírez, D., Lyamani, H., and Alados Arboledas, L.: Extreme Saharan dust event over the southern Iberian Peninsula in september 2007: active and passive remote sensing from surface and satellite, Atmos. Chem. Phys., 9, 8453 8469, doi:10.5194/acp-9-8453-2009, 2009.

Guibert, S., Matthias, V., Schulz, M., Bösenberg, J., Eixmann, R., Mattis, I., Pappalardo, G., Perrone, M. R., Spinelli, N., and Vaughan, G.: The vertical distribution of aerosol over Europe: synthesis of one year of EARLINET aerosol lidar measurements and aerosol transport modeling with LMDzT-INCA, Atmos. Environ., 39, 2933-2943, doi:10.1016/j.atmosenv.2004.12.046, 2005.

Heese, B., Flentje, H., Althausen, D., Ansmann, A., and Frey, S.: Ceilometer lidar comparison: backscatter coefficient retrieval and signal-to-noise ratio determination, Atmos. Meas. Tech., 3, 1763-1770, doi:10.5194/amt-3-1763-2010, 2010.

Illingworth, A. J., Barker, H. V., Beljaars, A., Chepfer, H., Delanoe, J., Domenech, C., Donovan, D. P., Fukuda, S., Hirakata, M., Hogan, R. J., Huenerbein, A., Kollias, P., Kubota, T., Nakajima, Nakajima, T. Y., Nishizawa, T., Ohno, Y., Okamoto, H., Oki, R., Sato, K., Satoh, M., Wehr, T., and Wandinger, U.: The EarthCARE satellite: the next step forward in global measurements of clouds, aerosols, precipitation and radiation, B. Am. Meteorol. Soc., submitted, 2014.

Ingmann, P., Veihelmann, B., Langen, J., Lamarre, D., Stark, H., and Bazalgette Courrèges-Lacoste, G.: Requirements for the GMES Atmosphere Service and ESA's implementation concept: sentinels-4/-5 and -5p, Remote Sens. Environ., 120, 58-69, doi:10.1016/j.rse.2012.01.023, 2012.

Lopatin, A., Dubovik, O., Chaikovsky, A., Goloub, P., Lapyonok, T., Tanré, D., and Litvinov, P.: Enhancement of aerosol characterization using synergy of lidar and sun-photometer coincident observations: the GARRLiC algorithm, Atmos. Meas. Tech., 6, 2065-2088, doi:10.5194/amt-6-2065-2013, 2013.

Mamouri, R. E. and Ansmann, A.: Fine and coarse dust separation with polarization lidar, Atmos. Meas. Tech. Discuss., 7, 51735221, doi:10.5194/amtd-7-5173-2014, 2014. 
Mamouri, R. E., Papayannis, A., Amiridis, V., Müller, D., Kokkalis, P., Rapsomanikis, S., Karageorgos, E. T., Tsaknakis, G., Nenes, A., Kazadzis, S., and Remoundaki, E.: Multiwavelength Raman lidar, sun photometric and aircraft measurements in combination with inversion models for the estimation of the aerosol optical and physico-chemical properties over Athens, Greece, Atmos. Meas. Tech., 5, 1793-1808, doi:10.5194/amt-5-1793-2012, 2012.

Matthias, V. and Bösenberg, J.: Aerosol climatology for the planetary boundary layer derived from regular lidar measurements, Atmos. Res., 63, 221-245, 2002.

Matthias, V., Bösenberg, J., Freudenthaler, V., Amodeo, A., Balis, D., Chaikovsky, A., Chourdakis, G., Comeron, A., Delaval, A., de Tomasi, F., Eixmann, R., Hågård, A., Komguem, L., Kreipl, S., Matthey, R., Mattis, I., Rizi, V., Rodriguez, J. A., Simeonov, V., and Wang, X.: Aerosol lidar intercomparison in the framework of the EARLINET project. 1. Instruments, Appl. Optics, 43, 4, 961-976, 2004a.

Matthias, V., Balis, D., Bösenberg, J., Eixmann, R., Iarlori, M., Komguem, L., Mattis, I., Papayannis, A., Pappalardo, G., Perrone, M. R., and Wang, X.: Vertical aerosol distribution over Europe: statistical analysis of Raman lidar data from 10 European Aerosol Research Lidar Network (EARLINET) stations, J. Geophys. Res., 109, D18201, doi:10.1029/2004JD004638, 2004b.

Mattis, I., Ansmann, A., Wandinger, U., and Müller, D.: Unexpectedly high aerosol load in the free troposphere over central Europe in spring/summer 2003, Geophys. Res. Lett., 30, 2178, doi:10.1029/2003GL018442, 2003.

Mattis, I., Ansmann, A., Müller, D., Wandinger, U., and Althausen, D.: Multiyear aerosol observations with dual-wavelength Raman lidar in the framework of EARLINET, J. Geophys. Res., 109, D13203, doi:10.1029/2004JD004600, 2004.

Mattis, I., Mueller, D., Ansmann, A., Wandinger, U., Preissler, J., Seifert, P., and Tesche, M.: Ten years of multiwavelength Raman lidar observations of free-tropospheric aerosol layers over central Europe: geometrical properties and annual cycle, J. Gepohys. Res., 113, D20202, doi:10.1029/2007JD009636, 2008.

Mattis, I., Tesche, M., Grein, M., Freudenthaler, V., and Müller, D.: Systematic error of lidar profiles caused by a polarizationdependent receiver transmission: quantification and error correction scheme, Appl. Optics, 48, 2742-2751, 2009.

Mattis, I., Siefert, P., Müller, D., Tesche, M., Hiebsch, A., Kanitz, T., Schmidt, J., Finger, F., Wandinger, U., and Ansmann, A.: Volcanic aerosol layers observed with multiwavelength Raman lidar over central Europe in 2008-2009, J. Geophys. Res., 115, D00L04, doi:10.1029/2009JD013472, 2010.

Mattis, I., D’Amico, G., and Baars, H.: Single Calculus Chain Technical Part 2: Calculation of optical products, in preparation, 2014.

Meier, J., Tegen, I., Mattis, I., Wolke, R., Alados Arboledas, L., Apituley, A., Balis, D., Barnaba, F., Chaikovsky, A., Sicard, M., Pappalardo, G., Pietruczuk, A., Stoyanov, D., Ravetta, F., and Rizi, V.: A regional model of European aerosol transport: evaluation with sun photometer, lidar and air quality data, Atmos. Environ., 47, 519-532, doi:10.1016/j.atmosenv.2011.09.029, 2012.

Mona, L., Amodeo, A., Pandolfi, M., and Pappalardo, G.: Saharan dust intrusions in the Mediterranean area: three years of Raman lidar measurements, J. Geophys. Res., 111, D16203, doi:10.1029/2005JD006569, 2006.
Mona, L., Pappalardo, G., Amodeo, A., D’Amico, G., Madonna, F., Boselli, A., Giunta, A., Russo, F., and Cuomo, V.: One year of CNR-IMAA multi-wavelength Raman lidar measurements in coincidence with CALIPSO overpasses: Level 1 products comparison, Atmos. Chem. Phys., 9, 7213-7228, doi:10.5194/acp-97213-2009, 2009.

Mona, L., Amodeo, A., D’ Amico, G., Giunta, A., Madonna, F., and Pappalardo, G.: Multiwavelength Raman lidar observations of the Eyjafjallajökull volcanic cloud over Potenza, southern Italy, Atmos. Chem. Phys., 12, 2229-2244, doi:10.5194/acp-12-22292012, 2012.

Müller, D., Wandinger, U., and Ansmann, A.: Microphysical particle parameters from extinction and backscatter lidar data by inversion with regularization: theory, Appl. Optics, 38, 2346-2357, 1999.

Müller, D., Mattis, I., Wandinger, U., Ansmann, A., Althausen, D., Dubovik, O., Eckhardt, S., and Stohl, A.: Saharan dust over a central European EARLINET-AERONET site: Combined observations with Raman lidar and Sun photometer, J. Geophys. Res., 108, 4345, doi:10.1029/2002JD002918, D12, 2003.

Müller, D., Mattis, I., Ansmann, A., Wehner, B., Althausen, D., Wandinger, U., and Dubovik, O.: Closure study on optical and microphysical properties of a mixed urban and Arctic haze air mass observed with Raman lidar and Sun photometer, J. Geophys. Res., 109, D13206, doi:10.1029/2003JD004200, 2004.

Müller, D., Mattis, I., Wandinger, U., Ansmann, A., Althausen, D., and Stohl, A.: Raman lidar observations of aged Siberian and Canadian forest-fire smoke in the free tropospere over Germany in 2003: microphysical particle characterization, J. Geophys. Res., 110, D17201, doi:10.1029/2004JD005756, 2005.

Müller, D., Ansmann, A., Mattis, I., Tesche, M., Wandinger, U., Althausen, D., and Pisani, G.: Aerosol-type-dependent lidar ratio observed with Raman lidar, J. Geophys. Res., 112, D16202, doi:10.1029/2006JD008292, 2007a.

Müller, D., Mattis, I., Ansmann, A., Wandinger, U., Ritter, C., and Kaiser, D.: Multiwavelength Raman lidar observations of particle growth during long-range transport of forest-fire smoke in the free trosposphere, Geophys. Res. Lett., 34, L05803, doi:10.1029/2006GL027936, 2007b.

Navas-Guzmán, F., Bravo-Aranda, J., Guerrero-Rascado, J., Granados-Muñoz, M., and Alados-Arboledas, L.: Statistical analysis of aerosol optical properties retrieved by Raman lidar over Southeastern Spain, Tellus B, 65, 21234, doi:10.3402/tellusb.v65i0.21234, 2013a.

Navas-Guzmán, F., Müller, D., Bravo-Aranda, J. A., GuerreroRascado, J. L., Granados- Muñoz, M. J., Pérez-Ramírez, D., Olmo, F. J., and Alados-Arboledas, L.: Eruption of the Eyjafjallajökull Volcano in spring 2010: multiwavelength Raman lidar measurements of sulphate particles in the lower troposphere, J. Geophys. Res.-Atmos., 118, 1804-1813, doi:10.1002/jgrd.50116, 2013b.

Nickovic, S., Kallos, G., Papadopoulos, A., and Kakaliagou, O.: A model for prediction of desert dust cycle in the atmosphere, J. Geophys. Res., 106, 18113-18129, 2001.

Papayannis, A., Amiridis, V., Mona, L., Tsaknakis, G., Balis, D., Bösenberg, J., Chaikovski, A., De Tomasi, F., Grigorov, I., Mattis, I., Mitev, V., Müller, D., Nickovic, S., Pérez, C., Pietruczuk, A., Pisani, G., Ravetta, F., Rizi, V., Sicard, M., Trickl, T., Wiegner, M., Gerding, M., Mamouri, R. E., D’Amico, G., and Pap- 
palardo, G.: Systematic lidar observations of Saharan dust over Europe in the frame of EARLINET (2000-2002), J. Geophys. Res., 113, D10204, doi:10.1029/2007JD009028, 2008.

Pappalardo, G., Amodeo, A., Pandolfi, M., Wandinger, U., Ansmann, A., Bosenberg, J., Matthias, V., Amiridis, V., De Tomasi, F., Frioud, M., Iarlori, M., Komguem, L., Papayannis, A., Rocadenbosch, F., and Wang, X.: Aerosol lidar intercomparison in the framework of the EARLINET project. 3. Raman lidar algorithm for aerosol extinction, backscatter and lidar ratio, Appl. Optics, 43, 5370-5385, 2004a.

Pappalardo, G., Amodeo, A., Mona, L., Pandolfi, M., Pergola, N., and Cuomo, V.: Raman lidar observations of aerosol emitted during the 2002 Etna eruption, Geophys. Res. Lett., 31, L05120, doi:10.1029/2003GL019073, 2004b.

Pappalardo, G., Wandinger, U., Mona, L., Hiebsch, A., Mattis, I., Amodeo, A., Ansmann, A., Seifert, P., Linne, H., Apituley, A., Alados Arboledas, L., Balis, D., Chaikovsky, A., D’Amico, G., De Tomasi, F., Freudenthaler, V., Giannakaki, E., Giunta, A., Grigorov, I., Iarlori, M., Madonna, F., Mamouri, R.-E., Nasti, L., Papayannis, A., Pietruczuk, A., Pujadas, M., Rizi, V., Rocadenbosch, F., Russo, F., Schnell, F., Spinelli, N.,Wang, X., and Wiegner, M.: EARLINET correlative measurements for CALIPSO: first intercomparison results, J. Geophys. Res., 115, D00H19, doi:10.1029/2009JD012147, 2010.

Pappalardo, G., Mona, L., D’Amico, G., Wandinger, U., Adam, M., Amodeo, A., Ansmann, A., Apituley, A., Alados Arboledas, L., Balis, D., Boselli, A., Bravo-Aranda, J. A., Chaikovsky, A., Comeron, A., Cuesta, J., De Tomasi, F., Freudenthaler, V., Gausa, M., Giannakaki, E., Giehl, H., Giunta, A., Grigorov, I., Groß, S., Haeffelin, M., Hiebsch, A., Iarlori, M., Lange, D., Linné, H., Madonna, F., Mattis, I., Mamouri, R.-E., McAuliffe, M. A. P., Mitev, V., Molero, F., Navas-Guzman, F., Nicolae, D., Papayannis, A., Perrone, M. R., Pietras, C., Pietruczuk, A., Pisani, G., Preißler, J., Pujadas, M., Rizi, V., Ruth, A. A., Schmidt, J., Schnell, F., Seifert, P., Serikov, I., Sicard, M., Simeonov, V., Spinelli, N., Stebel, K., Tesche, M., Trickl, T., Wang, X., Wagner, F., Wiegner, M., and Wilson, K. M.: Four-dimensional distribution of the 2010 Eyjafjallajökull volcanic cloud over Europe observed by EARLINET, Atmos. Chem. Phys., 13, 4429-4450, doi:10.5194/acp-13-4429-2013, 2013.

Pérez, C., Nickovic, S., Pejanovic, G., Baldasano, J. M., and Özsoy, E.: Interactive dustradiation modeling: a step to improve weather forecasts, J. Geophys. Res., 111, D16206, doi:10.1029/2005JD006717, 2006a.

Pérez, C., Nickovic, S., Baldasano, J. M., Sicard, M., Rocadenbosch, F., and Cachorro, V. E.: A long Saharan dust event over the western Mediterranean: lidar, Sun photometer observations, and regional dust modeling, J. Geophys. Res., 111, D15214, doi:10.1029/2005JD006579, 2006b.

Pérez, C., Nickovic, S., Pejanovic, G., Baldasano, J. M., and Ozsoy, E.: Interactive dustradiation modeling: a step to improve weather forecasts, J. Geophys. Res., 11, D16206, doi:10.1029/2005JD006717, 2006c.

Preißler, J., Wagner, F., Guerrero-Rascado, J. L., and Silva, A. M.: Two years of free tropospheric aerosol layers observed over Portugal by lidar, J. Geophys. Res.-Atmos., 118, 3676-3686, doi:10.1002/jgrd.50350, 2013.

Sawamura, P., Vernier, J. P., Barnes, J. E., Berkoff, T. A., Welton, E. J., Allados-Arboledas, L., Navas-Guzmán, F., Pappalardo, G.,
Mona, L., Madonna, F., Lange, D., Sicard, M., Godin-Beekmann, S., Payen, G., Wang, Z., Hu, S., Tripathi, S. N., CordobaJabonero, C., and Hoff, R. M.: Stratospheric AOD after the 2011 eruption of Nabro volcano measured by lidars over the Northern Hemisphere, Environ. Res. Lett., 7, 034013, doi:10.1088/17489326/7/3/034013, 2012.

Shipley, S. T., Tracy, D. H., Eloranta, E. W., Trauger, J. T., Sroga, J. T., Roesler, F. L., and Weinman, J. A.: A High Spectral Resolution Lidar to measure optical scattering properties of atmospheric aersols, Part I: Intrumentation and theory, Appl. Optics, 23, 3716-3724, 1983.

Sicard, M., Guerrero-Rascado, J. L., Navas-Guzmán, F., Preißler, J., Molero, F., Tomás, S., Bravo-Aranda, J. A., Comerón, A., Rocadenbosch, F., Wagner, F., Pujadas, M., and Alados-Arboledas, L.: Monitoring of the Eyjafjallajökull volcanic aerosol plume over the Iberian Peninsula by means of four EARLINET lidar stations, Atmos. Chem. Phys., 12, 3115-3130, doi:10.5194/acp-12-31152012, 2012.

Stoffelen, A., Pailleux, J., Källén, E., Vaughan, J. M., Isaksen, L., Flamant, P., Wergen, W., Andersson, E., Schyberg, H., Culoma, A., Meynart, R., Endemann, M., and Ingmann, P.: The atmospheric dynamics mission for global wind field measurement, B. Am. Meteorol. Soc., 86, 73-87, 2005.

Tesche, M., Müller, D., Ansmann, A., Hu, M., and Zhang, Y. H.: Retrieval of microphysical properties of aerosol particles from one-wavelength Raman lidar and multiwavelength Sun photometer observations, Atmos. Environ., 42, 6398-6404, 2008.

Tesche, M., Ansmann, A., Müller, D., Althausen, D., Engelmann, R., Freudenthaler, V., and Groß, S.: Vertically resolved separation of dust and smoke over Cape Verde using multiwavelength Raman and polarization lidars during Saharan Mineral Dust Experiment 2008, J. Geophys. Res., 114, D13202, doi:10.1029/2009JD011862, 2009.

Van Gijsel, A., Mona, L., Pappalardo, G., and Swart, D.: VALID Satellite validation with lidar, ESA Publications Division, Final report, ESTEC Contract n. 18193/04/NL/AR, Noordwijk, the Netherlands, 2011.

Veselovskii, I., Kolgotin, A., Griaznov, V., Müller, D., Wandinger, U., and Whiteman, D.: Inversion with regularization for the retrieval of tropospheric aerosol parameters from multiwavelength lidar sounding, Appl. Optics, 41, 3685-3699, 2002.

Veselovskii, I., Dubovik, O., Kolgotin, A., Korenskiy, M., Whiteman, D. N., Allakhverdiev, K., and Huseyinoglu, F.: Linear estimation of particle bulk parameters from multi-wavelength lidar measurements, Atmos. Meas. Tech., 5, 1135-1145, doi:10.5194/amt-5-1135-2012, 2012.

Villani, M. G., Mona, L., Maurizi, A., Pappalardo, G., Tiesi, A., Pandolfi, M., D'Isidoro, M., Cuomo, V., and Tampieri, F.: Transport of volcanic aerosol in the troposphere: the case study of the 2002 Etna plume, J. Geophys. Res., 111, D21102, doi:10.1029/2006JD007126, 2006.

Wagner, J., Ansmann, A., Wandinger, U., Seifert, P., Schwarz, A., Tesche, M., Chaikovsky, A., and Dubovik, O.: Evaluation of the Lidar/Radiometer Inversion Code (LIRIC) to determine microphysical properties of volcanic and desert dust, Atmos. Meas. Tech., 6, 1707-1724, doi:10.5194/amt-6-1707-2013, 2013.

Wandinger, U., Mattis, I., Tesche, M., Ansmann, A., Bösenberg, J., Chaikovski, A., Freudenthaler, V., Komguem, L., Linné, H., Matthias, V., Pelon, J., Sauvage, L., Sobolewski, P., Vaughan, 
G., and Wiegner, M.: Air mass modification over Europe: EARLINET aerosol observations from Wales to Belarus, J. Geophys. Res., 109, D24205, doi:10.1029/2004JD005142, 2004.

Wandinger, U., Tesche, M., Seifert, P., Ansmann, A., Müller, D., and Althausen, D.: Size matters: influence of multiple scattering on CALIPSO light-extinction profiling in desert dust, Geophys. Res. Lett., 37, L10801, doi:10.1029/2010GL042815, 2010.

Wandinger, U., Hiebsch, A., Mattis, I., Pappalardo, G., Mona, L., and Madonna, F.: Aerosols and Clouds: long-term Database from Spaceborne Lidar Measurements, ESA Publications Division, Final report, ESTEC Contract 21487/08/NL/HE, Noordwijk, the Netherlands, 2011.

Wandinger, U., Freudenthaler, V., Baars, H., Amodeo, A., Engelmann, R., Mattis, I., Groß, S., Pappalardo, G., Giunta, A., D’Amico, G., Chaikovsky, A., Osipenko, F., Slesar, A., Nicolae, D., Belegante, L., Talianu, C., Serikov, I., Linné, H., Jansen, F., Apituley, A., Wilson, K., de Graaf, M., Trickl, T., Giehl, H., Adam, M., Comeron, A., Rocadenbosch, F., Sicard, M., Pujadas, M., Molero, F., Alados-Arboledas, L., Preißler, J., Wagner, F., Pereira, S., Lahnor, B., Gausa, M., Grigorev, I., Stoyanov, D., Iarlori, M., and Rizi, V.: EARLINET instrument intercomparison campaigns: overview on strategy and results, Atmos. Meas. Tech. Discuss., in preparation, 2014.

Wang, X., Boselli, A., D’Avino, L., Pisani, G., Spinelli, N., Amodeo, A., Chaikovsky, A., Wiegner, M., Nickovic, S., Papayannis, A., Perrone, M. R., Rizi, V., Sauvage, L., and Stohl, A.: Volcanic dust characterization by EARLINET during Etna's eruptions in 2001-2002, Atmos. Environ., 42, 893-905, 2008.

Weitkamp, C. (Ed.): Lidar: Range-resolved Optical Remote Sensing of the Atmosphere, Springer Series in Optical Sciences, Springer, New York, USA, 2005.
Wiegner, M. and Geiß, A.: Aerosol profiling with the Jenoptik ceilometer CHM15kx, Atmos. Meas. Tech., 5, 1953-1964, doi:10.5194/amt-5-1953-2012, 2012.

Wiegner, M., Groß, S., Freudenthaler, V., Schnell, F., and Gasteiger, J.: The May/June 2008 Saharan Dust Event over Munich: intensive Aerosol parameters from lidar measurements, J. Geophys. Res., 116, D23213, doi:10.1029/2011JD016619, 2011.

Wiegner, M., Gasteiger, J., Groß, S., Schnell, F., Freudenthaler, V., and Forkel, R.: Characterization of the Eyjafjallajökull ashplume: potential of lidar remote sensing, J. Phys. Chem. Earth, 45-46, 79-86, doi:10.1016/j.pce.2011.01.006, 2012.

Wiegner, M., Madonna, F., Binietoglou, I., Forkel, R., Gasteiger, J., Geiß, A., Pappalardo, G., Schäfer, K., and Thomas, W.: What is the benefit of ceilometers for aerosol remote sensing? An answer from EARLINET, Atmos. Meas. Tech., 7, 1979-1997, doi:10.5194/amt-7-1979-2014, 2014.

Winker, D. M., Vaughan, M. A., Omar, A., Hu, Y., Powell, K. A., Liu, Z., Hunt, W. H., and Young, S. A.: Overview of the CALIPSO mission and CALIOP data processing algorithms, J. Atmos. Ocean. Tech., 26, 2310-2323, doi:10.1175/2009JTECHA1281.1, 2009.

WMO: Plan for the implementation of the GAW Aerosol Lidar Observation Network GALION (Hamburg, Germany, 27-29 March 2007), GAW Report no. 178, WMO TD No. 1443, World Meteorological Organization, Geneva, 2007.

WMO: Recommendations for a Composite Surface-Based Aerosol Network, GAW Report N. 207, Emmetten, Switzerland, 28-29 April 2009, 2012. 